\title{
RESEARCH, PRODUCTIVITY, AND OUTPUT GROWTH IN U.S. AGRICULTURE
}

\author{
KEITH FUGLIE* \\ Resources and Rural Economics Division, Economic Research Service, U.S. Department of Agriculture, \\ Washington, DC \\ MATTHEW CLANCY \\ Resources and Rural Economics Division, Economic Research Service, U.S. Department of Agriculture, \\ Washington, DC
}

PAUL HEISEY

Resources and Rural Economics Division, Economic Research Service, U.S. Department of Agriculture, Washington, DC

\section{JAMES MACDONALD}

Resources and Rural Economics Division, Economic Research Service, U.S. Department of Agriculture, Washington, DC

\begin{abstract}
This article reviews the current debate on whether U.S. agricultural productivity growth is slowing. It also assesses recent research on how productivity is related to long-term investment in research and development (R\&D). It describes significant changes taking place in the U.S. agricultural research system, including the growing role of private agribusiness as a main developer of new agricultural technologies and what this implies for agricultural science policy. The conclusion has suggestions for future research on these issues.
\end{abstract}

Keywords. Intellectual property rights, private R\&D, research crowding out, returns to research, technical change, total factor productivity

JEL Classifications. Q16, O3

\section{Introduction}

Agricultural economics research on sources of growth in U.S. agriculture agrees on two salient points: (1) nearly all growth in output over the past 70 years has come from productivity rather than factor accumulation, and (2) public investment in agricultural research and development (R\&D) is responsible for a dominant share of that productivity improvement (Alston and Pardey, 1996; Alston et al., 2010; Gardner, 2002; Huffman and Evenson, 1993; Ruttan, 2002;

The views expressed in this article are the authors' own and should not be attributed to the U.S. Department of Agriculture or the Economic Research Service.

*Corresponding author's e-mail: kfuglie@ers.usda.gov 
Wang et al., 2015). There is less consensus, however, on a number of material issues. One is the pattern of U.S. agricultural productivity growth over time-in particular, whether it has slowed recently. A second and related question is, to what extent does future productivity growth depend on raising spending levels for public agricultural R\&D? Other (potential) sources of new innovations for agriculture include nonagricultural sciences, foreign or international institutions, the business sector, and farmers themselves. Each of these players' relative contributions may shift over time. In particular, R\&D by agricultural input industries (providing seeds, chemicals, machinery, etc.) has grown considerably since the 1980s. Market forces and government policies influence the amount and direction of overall societal investment in agricultural innovation, and understanding the role of prices, policies, and interactions among research funders and performers carries considerable significance for the future direction of agricultural technology development and productivity growth.

The purpose of this article is to provide a review of recent research on trends and developments in aggregate agricultural growth and the role of policy in influencing that growth, with a focus on the United States. Although the data seem to indicate a clear decline in the rate of growth in real agricultural output, it is less clear whether that decline is the result of a contraction in total factors of production or a slowdown in the rate of productivity growth of those factors. We review trends in U.S. agricultural total factor productivity (TFP) using quality-adjusted, superlative indices of outputs and inputs constructed by the U.S. Department of Agriculture's Economic Research Service (USDA-ERS) (see Wang et al., 2015) and the University of Minnesota's International Science and Technology Practice and Policy (InSTePP) (as described in Alston, Beddow, and Pardey, 2009). A key difference in these indices is the construction of the capital input (its quantity and price), which implies a different growth pattern for total inputs and thus for TFP. ${ }^{1}$

Empirical models to explain the growth in agricultural TFP have assigned a leading role to public investments in agricultural R\&D. Recently, there have been several new studies that have estimated the elasticity of U.S. agricultural TFP with respect to R\&D. Most of this work has ignored potential sources of innovation from outside the public agricultural research system, either because the impact of these innovations is assumed to be captured in input costs (and therefore not part of TFP) or because they are considered spin-offs (adaptions) of public research. We review and critique this evidence and provide an explanation for why the new studies have found widely ranging (but nonetheless high) estimates of the social rate of return to public agricultural R\&D.

1 In growth accounting, the rate of growth in TFP is measured as the difference between growth in aggregate outputs and aggregate inputs. There is general agreement in the national pattern of real output growth in U.S. agriculture. Differences in the rate of TFP growth arise from differences in the way inputs are measured. 
To the extent that productivity growth in agriculture is dependent on expanding the stock of R\&D or knowledge capital, we would expect a slowdown in TFP to be preceded by a slowdown in the rate of growth in R\&D spending, with a lag to reflect the time it takes to translate R\&D spending into usable practices and technologies to apply on farms. In fact, spending on agricultural R\&D by federal and state governments, which rose rapidly throughout most of the 20th century, slackened after around 1980 and has declined in real terms since 2002. Complicating this picture, however, is a phenomenal rise in agricultural $\mathrm{R} \& \mathrm{D}$ investment by the business sector, especially in the crop seed and biotechnology industry (Clancy, Fuglie, and Heisey, 2016; Pardey et al., 2016). We describe public and private R\&D spending trends and review how changes in intellectual property rights (IPRs), environmental and safety regulations, the structure of agricultural input industries, and other factors may have influenced the amount and direction of private agricultural R\&D. We also review the evidence on whether the roles of public and private agricultural R\&D remain clearly defined or overlap and are duplicative. If public R\&D competes to provide similar technologies as private $\mathrm{R} \& \mathrm{D}$, it could lead to the "crowding out" of private R\&D. If public and private $R \& D$ are complementary, one could help stimulate more of the other.

The final section of the article has some suggestions for future research directions on the economics of the U.S. agricultural innovation system.

\section{Is There a Slowdown in Agricultural Productivity Growth?}

The tightening of global commodity supply-demand balances that gave way to sharp increases in world prices in 2007 and beyond has stimulated a discussion about whether a slowdown in the rate of agricultural productivity growth may have occurred (Alston, Beddow, and Pardey, 2009; Fuglie, 2008). A persisting slowdown could have profound implications for food price trends, given expectations for demand growth fueled by population and per capita income growth, particularly in developing countries, and by growing demand for biofuels. In turn, rising food prices could have significant consequences for living standards in less developed countries.

At the global level, rates of growth in harvested yield for several major crops have declined (Alston, Beddow, and Pardey, 2009). However, the long-term growth rate of total global agricultural output has not (Fuglie and Nin-Pratt, 2013). As simple growth accounting requires output growth to be the sum of the growth rates of agricultural inputs and the productivity of those inputs, it is hard to reconcile an apparent slowdown in productivity growth without a slowdown in output growth. In fact, studies that have attempted to estimate TFP growth rates for global agriculture find evidence of acceleration, not decline, mainly because the rates of growth in inputs (for land and labor in particular, but also for capital) have likely fallen over time (Fuglie, 2008, 2015). The evidence on 
global agricultural TFP growth suggests that the measured acceleration happened in developing countries (Fuglie and Wang, 2012; Fuglie, Wang, and Ball, 2012), although Ruttan (2002) expressed pessimism about whether such trends can continue.

For high-income countries-Europe in particular, but also the United States, Japan, and Australia-agricultural output growth has fallen in recent decades. However, even here, sluggish output growth does not necessarily imply a productivity slowdown. Land and labor resources have been leaving agriculture in developed countries, and slowing output growth could simply reflect a more rapid rate of resource withdrawal. Wang, Schimmelpfennig, and Fuglie (2012) reached this conclusion in their analysis of the growth in agricultural output and TFP in Western Europe over 1973-2002. Stagnation in output was accompanied by a substantial withdrawal of resources; TFP growth showed no signs of slowing over the period.

Assessments of long-term trends in U.S. agricultural TFP have been more contentious. Alston, Andersen, and Pardey (2015) present evidence of rising and then falling agricultural TFP growth rates. Their series shows some substantial differences with the agricultural TFP series developed by the USDA-ERS under the leadership of Eldon Ball, which they attribute mainly to how capital inputs are measured (Andersen, Alston, and Pardey, 2011). Because of the importance of this issue for the U.S. agricultural sector in addition to its academic interest, we review the debate in some detail subsequently.

The USDA series currently provides annual TFP growth estimates for the United States for 1948-2013. The national series consists of an output index (based in turn on 10 component indexes) and input indexes for capital (durable equipment, service buildings, land, and inventories), labor (hired labor and selfemployed), and intermediate inputs (feed and seed, energy, fertilizer and lime, pesticides, purchased services, and other). There have been major changes in labor, pesticide, and fertilizer attributes over time; ERS “quality adjusts" these series for changing attributes. ERS also quality adjusts its capital series for compositional changes among the detailed categories that make up the index.

The ERS data tell a by now familiar story, distinctive to agriculture (Figure 1). ${ }^{2}$ Agricultural output grew by $169.4 \%$ over $1948-2013$, or $1.52 \%$ per year. The aggregate input index grew by about 20\% between 1948 and 1980, but then fell back to its 1948 value by 1990, and has remained flat since then, with total inputs in 2013 only $3.4 \%$ greater than in $1948 .{ }^{3}$ Almost all output growth is

2 Jorgenson, Ho, and Samuels (2014) find that TFP accounted for only $23 \%$ of total U.S. economic growth during 1947-2010 and that farm-sector TFP grew much faster than the national average. Among 65 industries, the farm sector contributed a remarkable $7.5 \%$ share of total U.S. TFP growth over this period, the fifth highest.

3 There were substantial changes in input composition. Labor and land inputs fell over the periodquite sharply for labor-whereas the use of intermediate inputs such as fertilizers, chemicals, and 


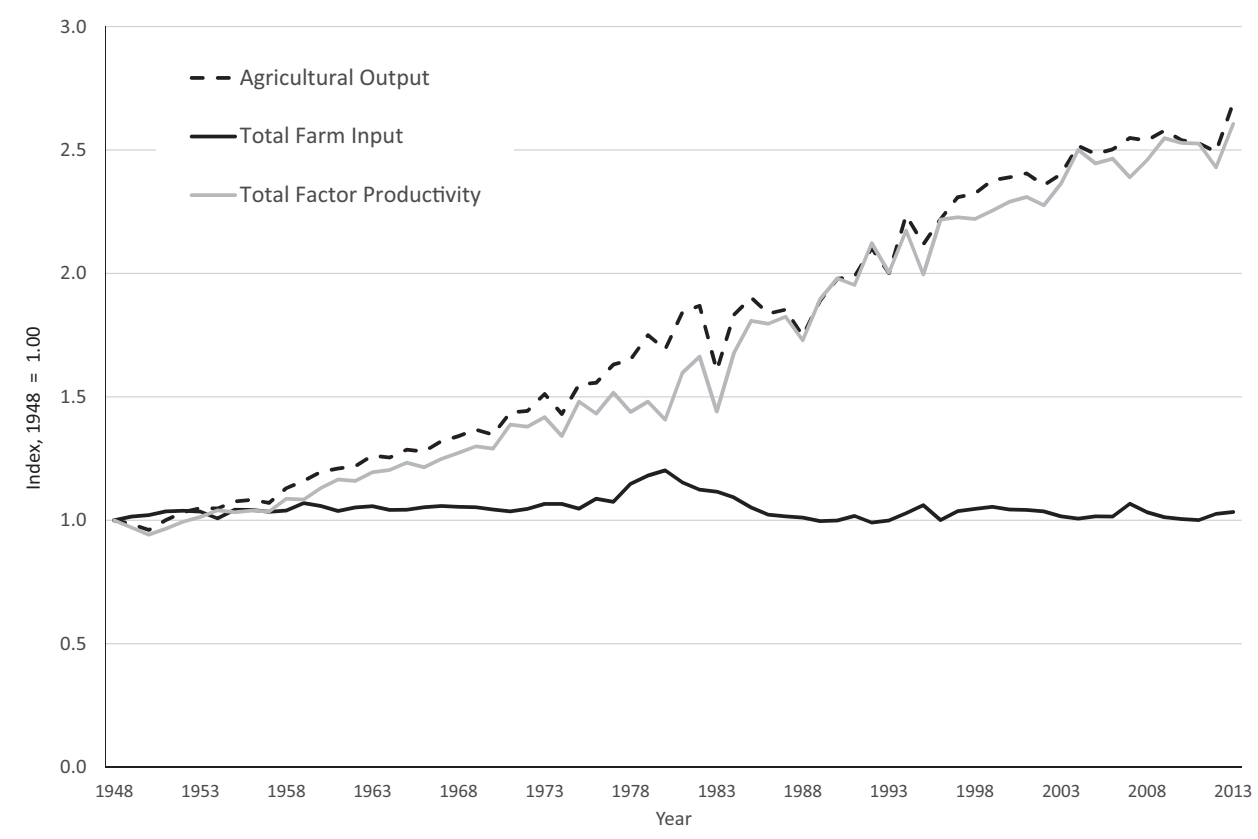

Figure 1. U.S. Agricultural Input, Output, and Total Factor Productivity, 19482013 (source: U.S. Department of Agriculture, Economic Research Service, 2015)

therefore accounted for by TFP growth, which comes out to $1.47 \%$ per year over 1948-2013.

Although agricultural output and TFP growth show strong trends over the period, there are sharp year-to-year variations in each (Figure 2). Annual TFP growth rates range from $-13.4 \%$ to $16.5 \%$, with an average annual absolute deviation from mean TFP growth of $3.77 \%$.

Annual fluctuations in TFP growth are highly correlated with fluctuations in output growth $(r=0.898)$, reflecting the effects of weather, and occasionally agricultural policy, on output. Poor weather years reduce output, with only small effects on farm inputs; similarly, years of good weather raise output and have only minor impacts on input flows.

Wide year-to-year fluctuations in TFP growth complicate the identification of shifts in TFP trends. For example, choosing decadal comparisons (19701980, 1980-1990, and 1990-2000) places great emphasis on the end-point years, which may happen to be strongly affected by weather and policy-related output shocks. Moreover, the available time series used in TFP analyses are not long, placing strain on formal tests of inference: the USDA-ERS series covers 65 years; Alston, Beddow, and Pardey (2009) covered 45 years; and

purchased services grew. The use of durable equipment and structures rose sharply until the early 1980 s and then fell. 


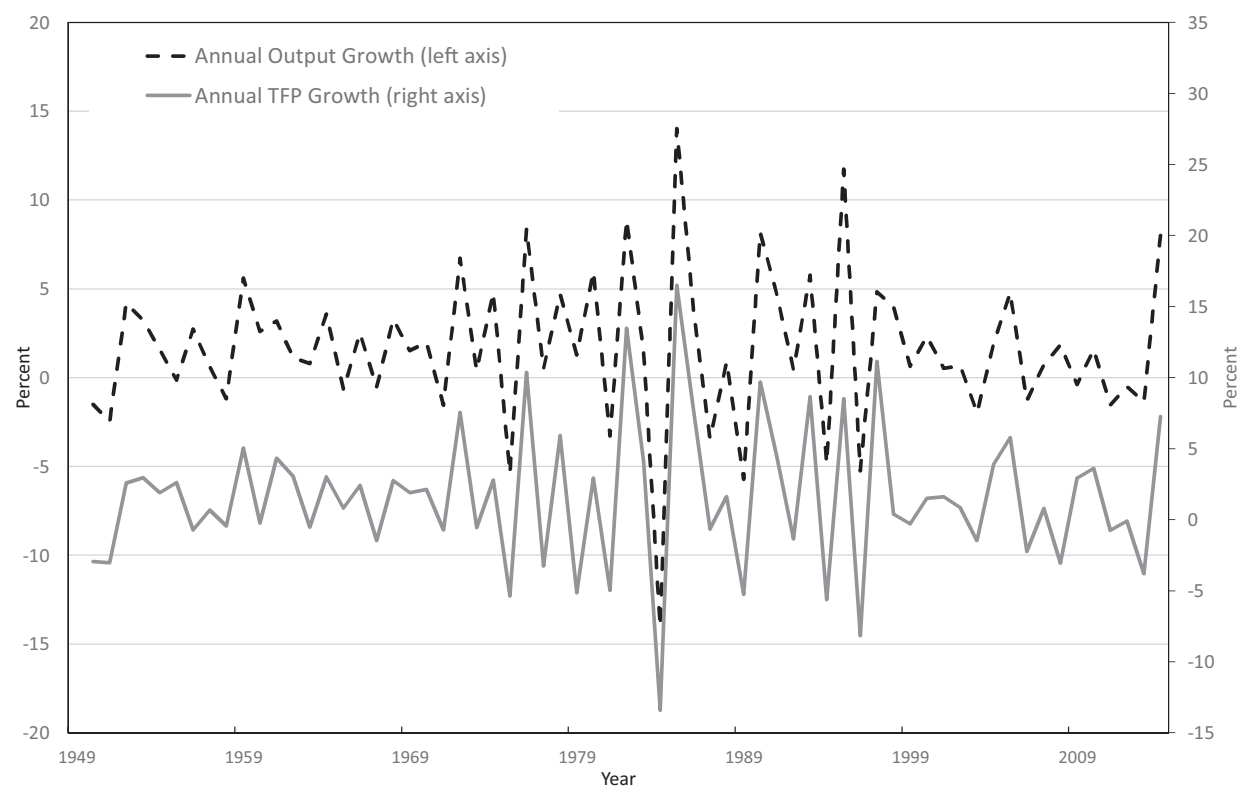

Figure 2. Annual Growth in U.S. Agricultural Output and Total Factor Productivity (TFP), 1949-2013 (source: U.S. Department of Agriculture, Economic Research Service, 2015)

Wang, Schimmelpfennig, and Fuglie' s (2012) test of a slowdown in European agricultural TFP covered 30 years.

In more recent studies, researchers continue to report trends in decadal or other arbitrary breaks for summary purposes but have moved to using various times series techniques to test for changes in trend rates of TFP growth. Ball, Schimmelpfennig, and Wang (2013) used times series tests to characterize the stochastic elements of the USDA-ERS TFP series and to identify separate intercept and slope shifts in the series over the period 1948-2009. They identified a modest but statistically significant trend break in 1974, with TFP growing at an annual rate of $1.71 \%$ over $1948-1974$ and at $1.57 \%$ over $1974-2009$. They also identified an intercept break in 1985 that shifted TFP up. When the USDAERS TFP series was later extended, however, the apparent post-1974 growth slowdown was no longer statistically significant (Wang et al., 2015). Revisions to methods and data series led to slightly slower TFP growth over the whole 19482011 period. They still found a significant intercept break (onetime, upward shift) at 1985 in the TFP series, which they thought could be the result of a combination of several factors, especially a severe drought and policies to reduce accumulated farm surpluses, that suppressed output (and thus productivity) in the early 1980s.

Alston, Andersen, and Pardey (2015) extended the temporal coverage of U.S. productivity, which allowed for an expanded sample size for testing and provided 
an opportunity to tell a more comprehensive story of research investments, innovation, and productivity growth. They did so by combining two data sets. One is their alternative U.S. agricultural multifactor productivity (MFP) series, from the InSTePP accounts at the University of Minnesota, which cover the United States and the contiguous 48 states from 1949 through 2007.4 The second is an older USDA-ERS series (USDA-ERS, 1983), which has indexes for output, land, and labor, and a two-factor MFP series, starting from $1910 .{ }^{5}$ After splicing the two series together, they then introduced a series of statistical tests aimed at identifying break points in trend movements of the MFP.

Specifically, Alston, Andersen, and Pardey (2015) ran a series of rolling regressions of the $\log$ of their MFP series on a time trend and on interaction terms for a trend shifter, with the shift allowed to increase year by year for each regression, which generated a rolling series of coefficients for trend break points. They fit a cubic polynomial trend model to the coefficient series and reported the inflection point, after which trend productivity growth starts to slow. They identify slowing MFP growth after the 1970s. They report that average MFP growth in 1990-2007 was $1.18 \%$ per year, compared with annual growth of $1.52 \%$ over their entire 1910-2007 period, and 1.97\% over 1950-1990.

Thus, Ball, Schimmelpfennig, and Wang (2013) find a modest slowdown, beginning in the 1970s, in the USDA-ERS TFP series, which they tie to capital investment and replacement incentives. However, even this slowdown becomes statistically insignificant using a longer and revised TFP series (Wang et al., 2015). Alston, Andersen, and Pardey (2015) argue, using the InSTePP TFP series, for a more pronounced slowdown, and they center it around 1990, a timing that places more emphasis on slowing public investments in R\&D.

Ongoing discussion has focused on the methods used to construct the indexes underlying the conflicting slowdown conclusions. Although they differ in a variety of ways-for example, the USDA-ERS series adjusts chemical inputs for changes in chemical attributes-a major focus of disagreement has been the measurement of capital.

In particular, the USDA series shows a large decline in the capital input between 1981 and 2001 (Wang et al., 2015); that decline is centered in durable equipment (Figure 3), which increases rapidly in 1973-1981-matching output

4 InSTePP uses the term MFP rather than TFP, but in the current context, they are equivalent concepts. In general, MFP refers to productivity measures that are based on more than one factor of production, but which usually omit some input (e.g., measures that include land and labor but omit intermediate inputs or capital). Alston and Pardey (2014) argue that all TFP measures are actually MFP because data limitations inevitably prohibit complete measurement of inputs. Documentation for the InSTePP accounts, along with aggregate data series for MFP, output, and four major inputs series, may be accessed at http: //www.instepp.umn.edu/united-states.

5 The older USDA series was supplanted by the methods introduced for the current series following the recommendations of an advisory task force (Gardner et al., 1980, Shumway et al., 2016). The measures of land, labor, and output are substantially different in construction and in their trends. 


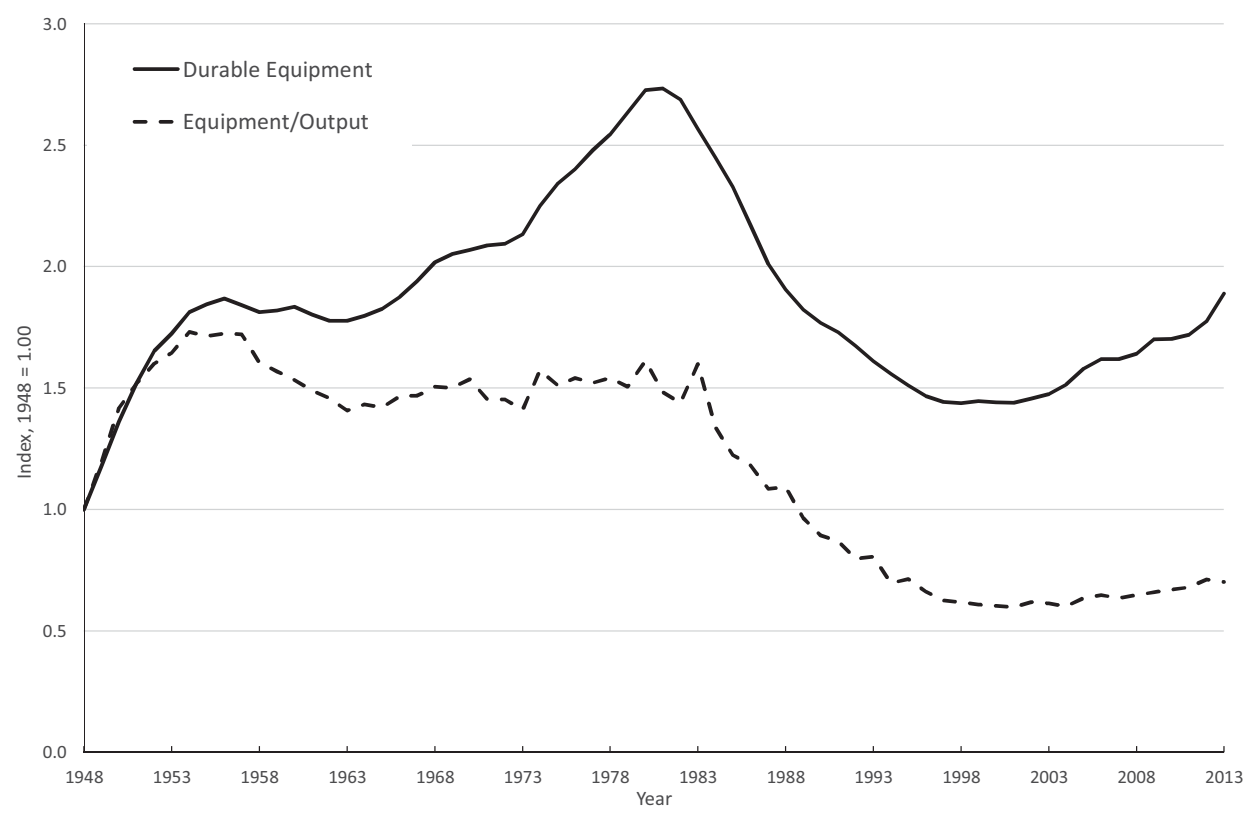

Figure 3. Durable Equipment Use in U.S. Agriculture (source: U.S. Department of Agriculture, Economic Research Service, 2015)

growth-and then declines quite sharply in 1981-2001, before beginning a steady increase again. The post-1981 decline in the capital input contributes to the decline in total inputs after 1981 (Figure 1) and leaves measured TFP growth higher than it would be if input growth had been more rapid.

The capital series for the USDA-ERS and InSTePP accounts follow a common theoretical framework, in which real capital stocks are created for different classes of assets, and those stocks are weighted by a rental price of capital for each class, which serves as weights in the construction of a capital stock. However, they are constructed in much different ways.

The USDA-ERS capital stock is based on financial data on real farm-sector investment, by asset class, and cumulated over time, while taking account of the declining efficiency and eventual mortality of past investment. The associated rental rates are based on the price of the capital asset, assumed capacity depreciation of the asset, and the ex ante real rate of return (Ball et al., 2016). The real rate of return is the nominal yield on investment grade corporate bonds, minus the expected rate of asset price inflation (based on an autoregressive integrated moving average [ARIMA] estimation process).

The InSTePP procedure builds up a capital stock based on physical inventories of assets of various types, drawing from Census of Agriculture reports on selected equipment in place on farms in census years, as well as data on equipment sales 
drawn from the Association of Equipment Manufacturers. Rental rates in the InSTePP accounts are based on a fixed real interest rate of $4 \%$.

The resulting capital series differ starkly for the 1980s. Andersen, Alston, and Pardey (2011) contend that the USDA-ERS series is not believable and argue strongly for assuming a fixed rate of interest in rental rates. The USDAERS response takes two channels. First, standard economic theory predicts real interest rates will exert a major influence on capital stock, and the periods under review have seen substantial and persistent movements in real interest rates (Bean et al., 2015; Council of Economic Advisors, 2015). ${ }^{6}$ Second, the decline in durable equipment capital summarized in Figure 3 reflects more than the direct effect of rental rates. Partly in response to the farm financial crisis of the 1980s, which in turn was influenced by the sharp rise in real rates, farmers began to rely more on equipment leasing and on the purchase of custom services. Those inputs are measured as other intermediate inputs in the USDA-ERS accounts and essentially represent a transfer of capital equipment from the farm sector, where it is measured as a capital input, to the leasing and agricultural services sectors, where it is measured as an intermediate input. ${ }^{7}$

One interpretation of the differences in the USDA-ERS and InSTePP approaches to measuring capital inputs is what they assume about the optimality of capital stocks. Conceptually, the flow of services from capital stock should be valued at its marginal product in order to capture its contribution to output. In equilibrium, producers maintain a stock of capital so that its marginal product just equals its user cost, which is influenced by the real interest rate. However, if the interest rate changes unexpectedly and persistently, a period of disequilibrium may ensue as producers adjust their capital stock to reflect the new market price of capital. Although the USDA-ERS procedure attempts to take into account expectations about future inflation in estimating ex ante real interest rates, it implicitly assumes perfect foresight and therefore continuous equilibrium in the farm stock of capital. The InSTePP approach, on the other hand, by assuming a permanently fixed interest rate, may be imposing a persistent disequilibrium condition by not allowing producers to expand or contract their capital stock in light of secular changes in the cost of capital. As Shumway et al. (2015, p. 57), in a comparative assessment of the USDA-ERS and InSTePP approaches, concluded, "If market interest rate volatility is not impacting agricultural capital services, a clear explanation is needed why agriculture is different from other sectors of the manufacturing and service economy. If agriculture is not substantially different

6 The evidence points to real long-term rates rising to about $4 \%$ to $6 \%$ in the later 1980 s from near zero in the late 1970 s and then falling steadily from the mid-1990s to near zero values today (Bean et al., 2015).

7 A related point: if agricultural equipment sales are made to leasing firms, then counting equipment sales as additions to farm-sector capital stocks runs the risk of double counting inputs, because their services will be counted in intermediate inputs. 


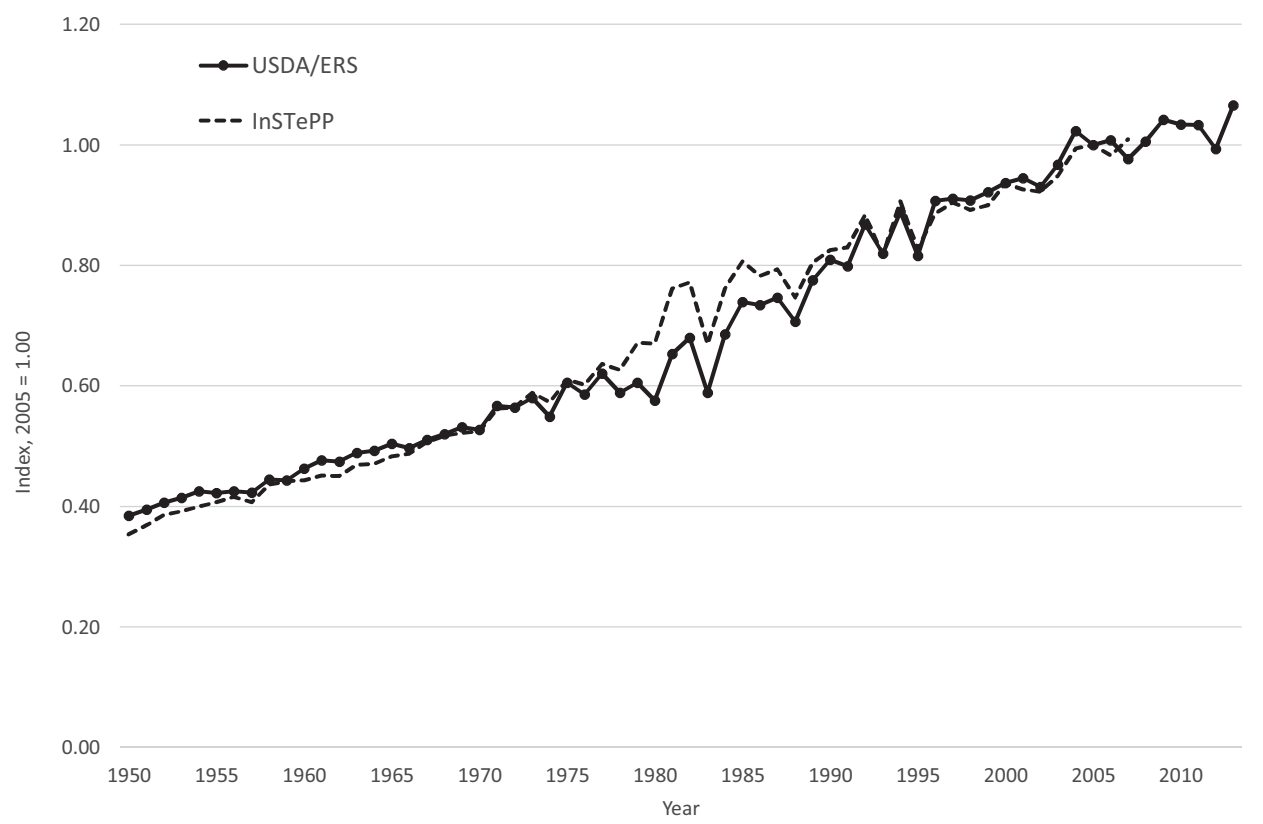

Figure 4. U.S. Department of Agriculture, Economic Research Service (USDAERS) and International Science and Technology Practice and Policy (InSTePP) Total Factor Productivity Indexes for U.S. Agriculture (sources: USDA-ERS, 2015; Pardey et al., 2012)

from other firms, then it cannot be argued that agriculture is insensitive to the market interest rate in its demand for capital.”

In spite of significant differences in methods, it is worth noting the degree of agreement in USDA-ERS and InSTePP measures. Both attribute nearly all of the growth in real output in U.S. agriculture since the mid-20th century to productivity. Apart from the decade between 1978 and 1988-when real interest rates were highly volatile-both show a remarkably similar pattern in TFP growth since this time (Figure 4). However, the evidence of a slowdown in U.S. agricultural TFP growth seems to hinge on the questionable assumption of a fixed interest rate for the cost of capital. It has been difficult to extract a clear signal from the noise in TFP indexes that arise from the effects of nature and measurement error.

The recent external review of the USDA-ERS agricultural productivity accounts by Shumway et al. $(2015,2016)$ provides several recommendations for refining the measures of outputs, inputs, and TFP, but none of these are likely to significantly alter the main tendencies in these data. A more fundamental critique of TFP as a measure of agricultural performance is that it ignores consumption of environmental services by the sector. Although agriculture has become a very 
small part (about 1\%) of the U.S. economy, it has a much larger presence in terms of land and water use, nutrient loadings to water bodies, and greenhouse gas emissions. Changes in production technologies have significant implications for the use of these mostly nonmarket but socially valuable resources. Efforts to extend TFP toward a more comprehensive total resource productivity (TRP) index have solid conceptual foundations (Chambers, 2015) but limited empirical development to date (Gollop and Swinand, 1998).

\section{The Relationship between Research Investment and Productivity}

The innovations that give rise to modern productivity growth in agriculture are generally understood to come primarily from formal R\&D. ${ }^{8}$ Because of the structure of the farm economy (dominated by small, family-owned firms), inherent limitations in protecting intellectual property in biological inputs (because of self-replication), and the public good nature of some research, historically the public sector has been the dominant funder and performer of agricultural R\&D. As U.S. agricultural productivity began to take off in the mid-20th century, scholars (Griliches, 1964; Schultz, 1953) tried to quantify the contributions of public R\&D investment to this new source of agricultural growth. These and subsequent studies found strong links between public $\mathrm{R} \& \mathrm{D}$ and productivity growth in agriculture and determined that this public investment earned high social rates of return (for a review, see Fuglie and Heisey, 2007).

In formal models linking $R \& D$ spending to productivity growth, $R \& D$ is typically treated as a type of long-lived capital investment (creating "knowledge capital"), which is subject to eventual depreciation because of technological obsolescence. Knowledge capital differs from physical capital, however, because of its public good character-it is nonrival and, even with legal constructs like IPRs, at least partially nonexcludable. Thus, knowledge capital can generate large "spillovers"- benefits accruing beyond those anticipated by the investors or inventors. The gradual accumulation of knowledge capital, arising from the agricultural R\&D conducted by the USDA and state research institutes established in the 19th century, accounts for a large share of the U.S. agricultural productivity growth experienced in the 20th century. In fact, the slowdown in the rate of growth in public agricultural $R \& D$ spending that set in around 1980 was suggested by Alston et al. (2010) as a likely explanation for the post-1990 productivity slowdown observed in the InSTePP measure of U.S. agricultural TFP.

8 Formal R\&D refers to dedicated investments by governments and firms in knowledge discovery and development using scientific methods, as opposed to innovations that arise through informal processes like learning by doing and shop-floor tinkering. However, in some sectors, like farm machinery innovation, informal learning and experimentation have been a significant source of innovations (Evenson, 1982). 
A limitation of these models, however, is that the U.S. agricultural innovation system has undergone significant changes in the late 20th century. Perhaps the most prominent change has been the rising capacity of the private business sector in generating new agricultural technology (Fuglie and Toole, 2014). A second contributing factor is potential knowledge spillovers from nonagricultural sciences, especially from the integration of computational and life sciences, which the National Research Council has dubbed the "New Biology." Finally, even as U.S. public agricultural R\&D spending stagnated, it continued to grow globally (Beintema et al., 2012), creating at least the possibility of greater international knowledge spillovers to U.S. agriculture.

In the remainder of this section, we first review trends in public and private agricultural R\&D spending in the United States. We then critique a set of recent studies that have reexamined the relationship between R\&D spending and TFP growth in U.S. agriculture.

\subsection{Trends in Agricultural R\&D Spending}

Globally, public and private spending on food and agricultural R\&D grew significantly in the first decade of this century, but with shifting loci from developed to developing countries and from the public to the private sectors (Beintema et al., 2012; Pardey et al., 2015). It has been difficult to obtain reliable data on private R\&D, however, and what gets counted in these estimates is often inconsistent or incomplete. For example, national surveys of business R\&D typically classify "private agricultural R\&D” as R\&D by business firms that primarily produce agricultural commodities. Although this may include R\&D by seed companies, it excludes agriculturally related R\&D by firms in the chemical, pharmaceutical, and machinery sectors. Rarely do national statistics sources report private R\&D by sector of intended use (Pray and Fuglie, 2015). Furthermore, many national and global estimates group private $R \& D$ by food companies together with R\&D by agricultural companies, even though most $\mathrm{R} \& \mathrm{D}$ in the food sector has little relevance for production agriculture (Fuglie et al., 2011).

Drawing on a survey of several hundred firms in seven agricultural input industries, ${ }^{10}$ Fuglie et al. (2011) provided the first comprehensive estimate of global private $R \& D$ intended for agriculture over 1994-2010, and these were recently extended to cover 1990 to 2014 (Fuglie, 2016). These studies found that agricultural R\&D by the business sector doubled in real terms over this period,

9 The National Research Council (2009) characterized "New Biology" as the integration of life sciences with physics, engineering, computational sciences, mathematics, and other disciplines, affording new opportunities for biological research to address pressing societal problems in food, the environment, energy, and health.

10 These input industries consist of crop seed and biotechnology, agricultural pesticides, fertilizers, animal breeding, animal health, animal feed, and farm machinery. 

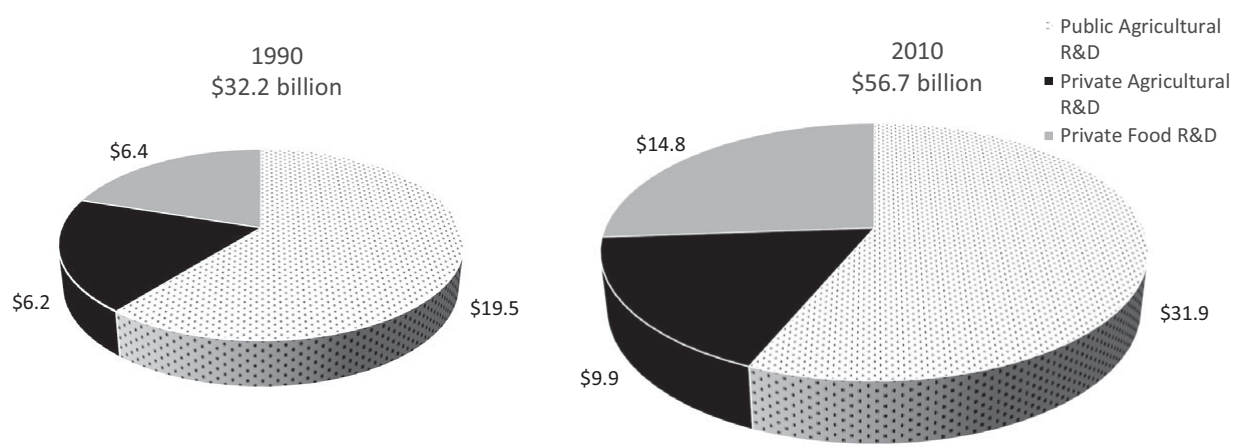

Figure 5. Global Spending on Public and Private Food and Agricultural R\&D, 1990 and 2010 (figures in constant 2005 purchasing-power-parity dollars, billions; sources: public R\&D in developing countries from Agricultural Science and Technology Indicators [International Food Policy Research Institute, 2016]; public R\&D spending in developed countries from P. Heisey and K. Fuglie [unpublished]; and private R\&D from Fuglie [2016]).

from $\$ 6.4$ billion in 1990 to $\$ 12.9$ billion in 2014 (constant 2005 purchasingpower-parity dollars [PPP\$]).

Using these updated figures for private $R \& D$ together with estimates of public $\mathrm{R} \& \mathrm{D}$, Figure 5 compares public and private spending on food and agricultural R\&D in 1990 and 2010. Total global spending on food and agricultural R\&D increased by $78 \%$ in constant PPP dollars, from $\$ 32.2$ billion to $\$ 56.7$ billion. The private share of the total increased from $39 \%$ to $44 \%$ over these two decades, although much of this growth was in R\&D by the food sector. Private R\&D oriented toward agriculture appears to have grown at about the same pace as public agricultural R\&D. The recent estimates by Fuglie (2016) show that in constant dollars, private agricultural R\&D remained flat from the 1990s till about 2002 and then nearly doubled between 2002 and 2013. Farm machinery and crop R\&D were the fastest-growing components of private agricultural $\mathrm{R} \& \mathrm{D}$ spending during this period.

Turning to the United States, for which longer time series data are available, recent trends indicate a dramatic change in the importance of the private sector as a source of R\&D for agriculture. Since 2010, private R\&D spending by agricultural input industries (for crop seeds and chemicals, animal health, breeding and nutrition, and farm machinery) has exceeded total spending by the federal-state system on agricultural research (Figure 6). In constant 2005 dollars (where nominal spending is adjusted by a cost-of-research price index), agricultural R\&D by the public sector peaked at about $\$ 4.9$ billion in 2002 and then declined to $\$ 3.6$ billion by 2013 . Private-sector agricultural R\&D, on the other hand, continued to grow during these years, and by 2013 the private sector was spending nearly $\$ 2$ billion more in agricultural research than 


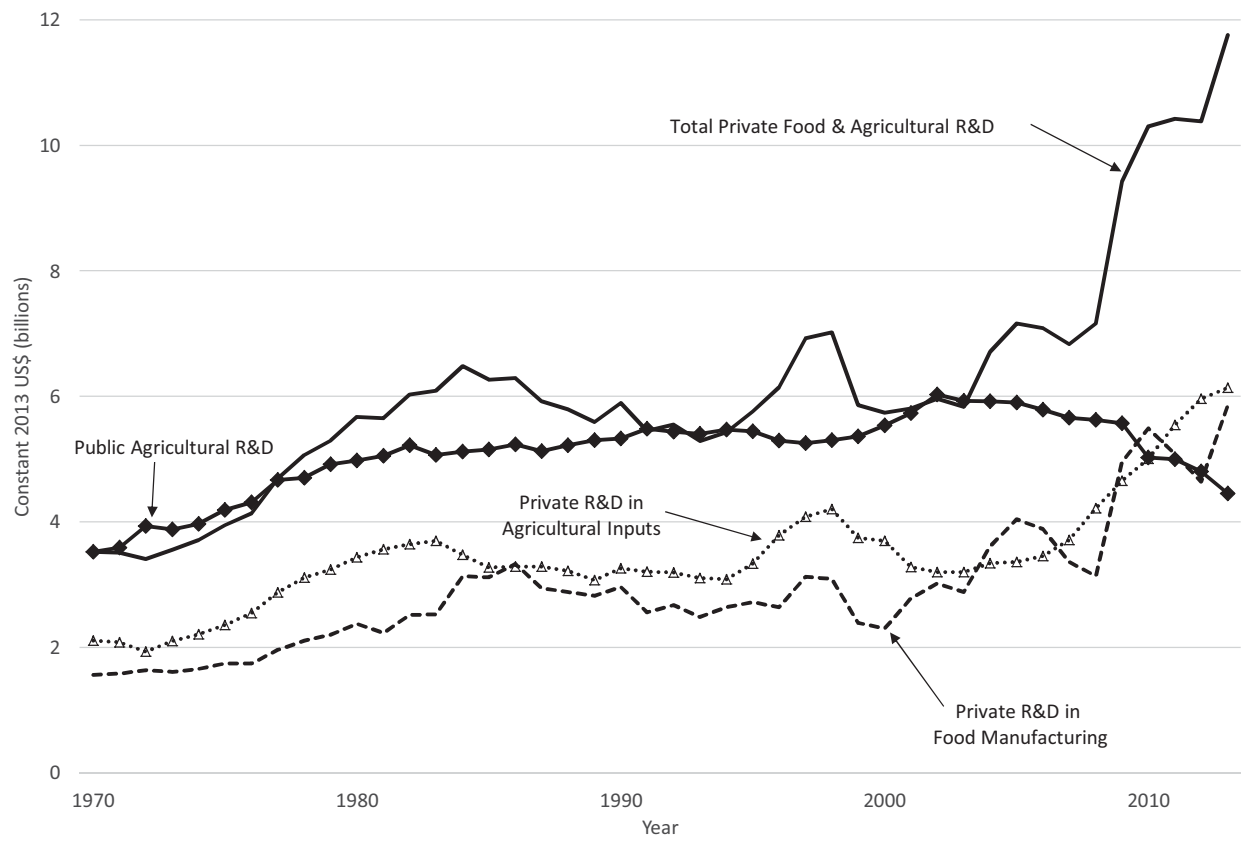

Figure 6. Public and Private Spending on Food and Agricultural R\&D in the United States, 1970-2013 (annual spending on research is adjusted for inflation by a research price index constructed by U.S. Department of Agriculture, Economic Research Service; source: Clancy, Fuglie, and Heisey, 2016).

the public sector. Growth in private R\&D was especially pronounced in the crop seed and biotechnology sector, which emerged as a significant R\&D-based industry in the 1990s. By 2014, more than $40 \%$ of total private agricultural R\&D in the United States was oriented toward crop genetic improvement and trait development. ${ }^{11}$

To understand the implications of these trends for food and agricultural innovation, it is useful to have a picture of who funds, and who performs, this R\&D. In 2013 (the latest year for which comprehensive estimates are available), federal, state, and private institutions funded and performed roughly $\$ 16.3$ billion worth of R\&D for food and agriculture in the United States (Figure 7). Of this total, the majority was funded and performed by the private sector. The federal government, through the USDA and other federal agencies, funded approximately $\$ 2.8$ billion of this $\mathrm{R} \& \mathrm{D}$. Of this amount, about $\$ 1.5$ billion

11 The growth in U.S. private R\&D shown in Figure 6 has also been documented by Pardey et al. (2016), although they only report estimates for food and agricultural R\&D combined. They estimate that between 1980 and 2011, U.S. private food and agricultural R\&D in the United States increased by $\$ 4.46$ billion (constant 2009 US\$). The comparable increase from Figure 6 implies an increase of $\$ 4.70$ billion (constant 2009 US\$) over these same years. 


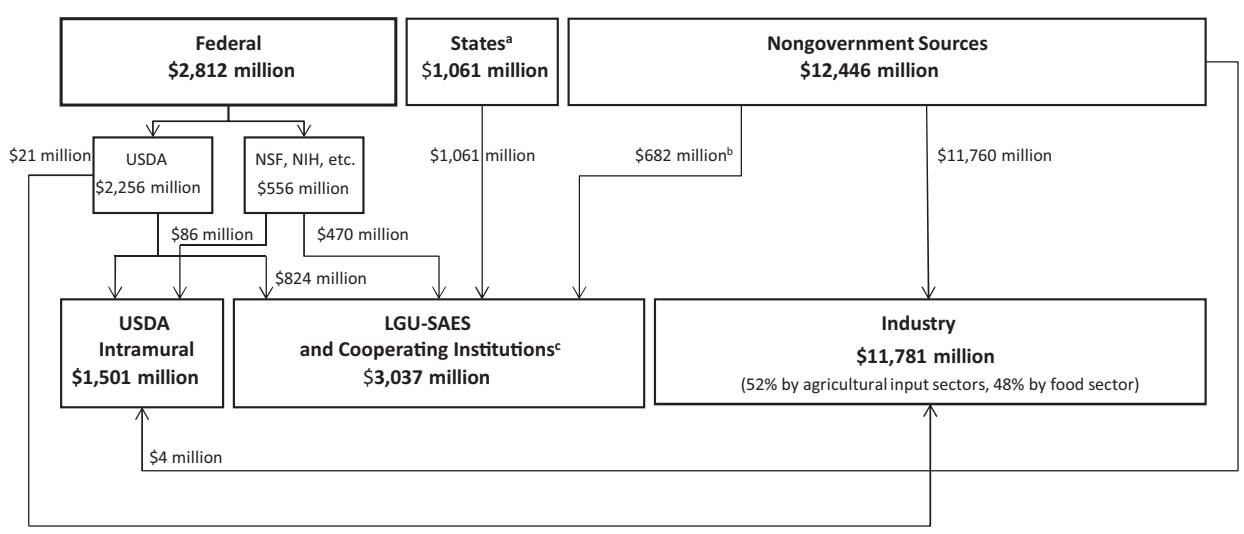

Figure 7. Funders and Performers of U.S. Food and Agricultural Research in 2013 (notes: ${ }^{a}$ standards of reporting of state-level public R\&D expenditures changed in 2010; ${ }^{\text {b }}$ nongovernment contributions to LGU-SAES (\$682 million) consisted of [1] research grants and contracts from private companies, [2] research grants from farm commodity groups, philanthropic foundations, other organizations, and individuals, and [3] revenue and fees from the sale of products, services, and technology licenses; ${ }^{c}$ LGU-SAES and cooperating institutions include the 1862 and 1890 land grant universities and state agricultural experiment stations and veterinary schools, forestry schools, and other U.S. colleges and universities receiving agricultural research funding from the U.S. Department of Agriculture [USDA]; source: Clancy, Fuglie, and Heisey, 2016)

worth of federally funded research was performed by USDA intramural research agencies. State institutions-land grant universities (LGUs), state agricultural experiment stations (SAES), and other cooperating institutions-received \$3.1 billion from all sources, including $\$ 1.3$ billion in federal monies, for agricultural R\&D. About two-thirds of the federal support for LGUs was channeled through the USDA and the rest from other federal agencies. State institutions received another $\$ 1.1$ billion from state governments and $\$ 0.7$ billion from nongovernment sources for research. Nongovernment sources include producer assessments, ${ }^{12}$ private companies, nonprofit foundations, and earnings from licensing fees and product sales. Research performed at USDA, LGU-SAES, and cooperating institutions is mostly oriented toward agriculture, but also

12 Federal and state legislation provide for mandatory or voluntary producer assessments ("checkoffs"), subject to majority support from participants, to be levied and used to support research and market promotion for specific agricultural commodities. The principal federal authorizing legislation for producer assessments is the Commodity Promotion, Research and Information Act of 1996. Most funds raised through assessments are used for generic advertising. The President's Council of Advisors on Science and Technology (2012) estimated that in 2009, 18 federally authorized checkoff programs contributed $\$ 132$ million to support public agricultural research in the United States. 
includes research on forestry, natural resources, food and nutrition, economics and statistics, and rural development.

Food and agricultural research performed by the private sector is financed almost entirely by for-profit companies and includes firms from several industries. Of the estimated $\$ 11.8$ billion in food and agricultural R\&D performed by these firms in 2013, just under half was by the food manufacturing industry, composed of firms that process raw agricultural commodities into food products. Research by these firms was heavily oriented to new product development or manufacturing process improvements, with only a small fraction oriented toward agricultural production (Conner, 1981; Fuglie et al., 2011; Galizzi and Venturini, 1996). The other half of private R\&D was by agricultural input manufacturers mainly to develop improved inputs for use on farms. This agriculturally oriented R\&D was performed by crop seed and livestock genetic companies, as well as by firms in a range of manufacturing industries (chemical, machinery, biotechnology, and pharmaceutical). In addition to the for-profit sector, some agricultural research is conducted by private, nonprofit institutes funded through charitable or government grants (these form a very small part of the system in terms of funds involved and are not shown in Figure 7).

\subsection{Models of TFP Determinants}

The effects of R\&D on productivity are typically modeled by treating R\&D spending as a long-lived capital investment. Knowledge capital accrues, with a lag, from past R\&D spending but eventually depreciates through technological obsolescence (Alston et al., 2010; Jin and Huffman, 2016). However, statistical quantification is confounded by the unobserved process of R\&D knowledge stock formation. Clearly the process of technological innovation-from discovery to development to farmer adoption-takes time, with each step subject to considerable uncertainty. Equally important is the uncertainty involved in the rate of knowledge depreciation. Past technologies may lose their effectiveness (because of the evolution of new biotic and abiotic stresses, for example) or become outdated by new scientific advances, whereas some knowledge discoveries could remain relevant for a century or more.

Empirical studies that have examined the relationship between R\&D expenditures and agricultural productivity growth have generally transformed R\&D spending into knowledge capital stocks using a set of lag weights and then regressed these stocks against an index of agricultural TFP (Alston et al., 2010; Huffman and Evenson, 1993, 2006) or otherwise estimated the weights using nonparametric methods (Chavas and Cox, 1992). The lag weights have been structured to embody key stages of technological innovation starting from initial research efforts toward commercial development and adoption of new technologies in the production system (Alston et al., 2010). Although this strategy is particularly useful in modeling the temporal transformation of R\&D spending to knowledge stocks, current methods clearly ignore the uncertainty in 
knowledge stock accumulation. Indeed, it is widely recognized that knowledge stocks are quite sensitive to the chosen lag weight structure and its corresponding model parameters (Alston et al., 2010). At the moment, the literature has addressed this issue by ranking a wide array of distributional parameters based on goodness of fit between reconstructed and observed growth-for example, minimizing root-mean-square errors (Alston et al., 2011). However, this ad hoc approach fails to formally incorporate the assessment of uncertainty in the conversion of R\&D expenditures to knowledge capital stocks and in the subsequent productivity gains from increased R\&D investments in agriculture. See Alston (2010) for a concise discussion of issues and challenges in measuring benefits of agricultural research on productivity.

U. Baldos, F. Viens, T. Hertel, and K. Fuglie (unpublished) develop a Bayesian econometric model of the effects of public R\&D on U.S. agricultural TFP growth. Bayesian inference provides detailed information about parameter and measurement uncertainty from which probabilistic statements over credibility intervals (the Bayesian counterpart of confidence intervals) can be derived. Although their Bayesian model generally supports previous findings of long time lags between R\&D spending and R\&D stock growth, Baldos et al. find that previous work has severely underestimated uncertainty surrounding the measurement of $\mathrm{R} \& \mathrm{D}$ stocks. One implication is that the framework based on public $\mathrm{R} \& \mathrm{D}$ spending alone remains incomplete as an explanation for the rate of technical change in agriculture.

\subsection{Recent Estimates of the Research-Productivity Relationship}

Over the last decade, a number of new studies have been published on the effects of public R\&D on agricultural productivity in the United States (Table 1). These studies include the period when private R\&D spending, particularly for seedbiotechnology research, was rising rapidly, and shed light on whether returns to public agricultural research remain high even as the agricultural innovation landscape is being transformed.

The seven studies listed in Table 1 evaluated the impact of total agricultural R\&D spending on national agricultural TFP growth, using either a single national time series or a panel of 48 contiguous states. In each study, TFP was regressed against a stock of research capital and other variables. Models using state panels included the effects of own-state R\&D and spillover R\&D from other states. Only two studies (Huffman and Evenson, 2006; Wang et al., 2013) included an explicit measure of private R\&D capital (although other studies included a time trend variable to account for the effects of unobserved factors).

Estimates of the marginal internal rate of return (IRR) to public agricultural research from the studies listed in Table 1 were all high, indicating that even by the early 21 st century substantial underinvestment in agricultural research was pervasive. The wide range in reported IRRs, between $17 \%$ and $67 \%$, is likely because of methodological differences, especially (1) assumptions about the 
Table 1. Recent Estimates of the Research-Productivity Relationship in U.S. Agriculture

\begin{tabular}{|c|c|c|c|c|c|c|}
\hline Study & Observation & Period & R\&D Lag Structure ${ }^{a}$ & $\begin{array}{l}\text { Elasticity of } \\
\text { Agricultural Research }\end{array}$ & $\begin{array}{l}\text { Social Rate of Return } \\
\text { to Research }(\%)\end{array}$ & $\begin{array}{l}\text { Measure of Public } \\
\text { Research }^{\text {b }}\end{array}$ \\
\hline $\begin{array}{l}\text { U. Baldos, F. Viens, T. Hertel, } \\
\text { and K. Fuglie (unpublished) }\end{array}$ & National & 1949-2011 & 50-year gamma & $\begin{array}{l}0.22 \\
(0.12-0.31)^{\mathrm{c}}\end{array}$ & $\begin{array}{l}17 \\
(12-22)^{\mathrm{c}}\end{array}$ & Gross \\
\hline Jin and Huffman (2016) & 48 States & 1970-2004 & 35-year trapezoid & 0.29 & 67 & Net \\
\hline Wang et al. (2013) & National & 1970-2009 & $\begin{array}{l}35 \text {-year inverted V } \\
19 \text {-year inverted V }\end{array}$ & $\begin{array}{l}0.43, \text { public } \\
0.14 \text {, private }\end{array}$ & Not estimated & Net \\
\hline Andersen and Song (2013) & National & 1949-2002 & 50-year gamma & 0.37 & 21 & Gross \\
\hline Wang et al. (2012) & 48 States & 1980-2004 & 35-year trapezoid & 0.29 & 45 & Net \\
\hline Alston et al. (2011) & 48 States & 1949-2002 & 50-year gamma & 0.29 & 23 & Gross \\
\hline Huffman and Evenson (2006) & 48 States & 1970-1999 & $\begin{array}{l}35 \text {-year trapezoid } \\
19 \text {-year trapezoid }\end{array}$ & $\begin{array}{l}0.35 \text {, public } \\
0.11, \text { private }\end{array}$ & $\begin{array}{l}56 \\
40\end{array}$ & Net \\
\hline \multicolumn{4}{|c|}{ Estimate range for public R\&D elasticity using "net" R\&D and short lag } & $0.29-0.43$ & $45-67$ & Net \\
\hline \multicolumn{4}{|c|}{ Estimate range for public R\&D elasticity using "gross" R\&D and long lag } & $0.22-0.37$ & $17-23$ & Gross \\
\hline
\end{tabular}

a Studies using a 50-year lag structure assume a longer total capital life of R\&D capital and a longer gestation period (about two decades) from initial research to full impact on productivity. Studies using shorter lag structures assume a shorter life span for R\&D capital and a shorter gestation period (a decade or less) to full impact on productivity.

bStudies using the "gross" measure of agricultural research expenditures includes all spending by U.S. Department of Agriculture and state institutions classified as agricultural research, except for forestry research. Studies using the "net" measure of agricultural research only include research judged to be directly related to farm production.

${ }^{\mathrm{c}}$ The range in parentheses is the $95 \%$ Bayesian credible interval for the estimates of the research elasticity and internal rate of return to research. 
R\&D lag structure and (2) what is included in the measure of public agricultural R\&D. Studies using a 50-year R\&D lag structure assumed that it took about two decades for $R \& D$ to have its peak effect on productivity, compared with one decade or less for studies using a 35-year or short R\&D lag structure. With a longer gestation period, the present value of the benefits of $R \& D$ could be considerably lower even though the R\&D capital is longer lived. Studies using the 50 -year R\&D lag structure also used a broader definition for public agricultural R\&D - they included all spending classified by the USDA as agricultural except forestry research (what is called "gross" R\&D in Table 1). Studies using "net" $R \& D$ expenditures only included productivity-oriented research ("net" $R \& D$ in the table). This excluded research on economics and statistics, natural resources, utilization, and some "basic science" categories like biology and genetics. It appears that the gross measure of research expenditure exceeds the net measure by as much as $30 \%$. Assuming the same level of benefits is achieved at a lower cost results in a higher IRR.

New insight into the R\&D lag structure was provided by U. Baldos, F. Viens, T. Hertel, and K. Fuglie (unpublished), who developed a Bayesian model that accounts for uncertainty in R\&D capital formation. Their analysis lends support to a longer R\&D lag distribution, finding a mean peak year for R\&D impact of 20 years with a $95 \%$ credible interval between 16 and 23 years. This is similar to the gestation period assumed using a 50-year R\&D lag structure and significantly longer than that assumed using 35-year and shorter R\&D lag structures. These findings apply only to the case of public agricultural R\&D in the United States. They could well be different in other settings.

Recently, Hurley, Rao, and Pardey (2014) criticized the use of IRR as a guide for ranking investments, especially highly profitable ones. They claim that the IRR measure is likely to exaggerate these returns because it implicitly assumes that the profits (or benefits) from the investment can be reinvested at the same IRR. Instead, they propose the modified internal rate of return (MIRR), in which an explicit reinvestment rate for benefits is assumed. Their reestimated MIRR for agricultural research is significantly lower than reported IRRs but is still high enough to justify the claim that agricultural research is a lucrative investment option for public policy. However, Oehmke (2017) has raised issues with the MIRR as well. He notes that the MIRR is sensitive to the planning horizon assumed for an investment project and may be poorly suited for representing returns to projects that have long but uncertain benefit horizons, like research. ${ }^{13}$

13 A simple example may help to illustrate the MIRR's sensitivity to alternative assumptions. Suppose $\$ 1$ is invested in research in year one, from which benefits of $\$ 2.5$ per year are obtained in years 10 through 30 . The IRR for this investment is $30 \%$. Assuming a borrowing rate of $3 \%$ and a reinvestment rate of $7 \%$, its MIRR is $18 \%$. However, if we only count benefits that accrue to year 14 (ignoring benefits after this date) the MIRR increases to $23 \%$ (whereas the IRR decreases to $26 \%$, as would be expected with fewer benefits). If we extend the horizon to 35 years, even though no benefits occur after year 30, the MIRR falls to $16 \%$. Although the MIRR has an intuitively attractive interpretation as the compounded rate of 
In fact, both the IRR and MIRR were developed from the perspective of a business firm seeking to rank alternative investments in order to maximize its net worth. Whether this objective applies equally well to a policy maker seeking to maximize the value of a social welfare function has been absent from this discussion.

Measuring the contribution of private $R \& D$ to farm productivity remains another challenge for this literature. Data on private R\&D are proprietary, and available estimates, like those in Figure 6, are highly aggregate and subject to measurement error. For example, the estimates in Figure 6 show R\&D spending by U.S. firms, whether conducted in the United States or elsewhere, and do not include R\&D spending by foreign companies in the United States. At a more conceptual level, much of benefits from private R\&D may not accrue to the farm sector at all but accrue as profits to the input supply industries. Wang et al. (2013), using aggregate national time series for public and private R\&D, found that the estimated R\&D elasticities were sensitive to the lag structure used to construct research stocks from expenditures. To construct a state-level panel of private R\&D, Huffman and Evenson (2006) used the number of crop and livestock patents assigned to states according to the address of the patent assignee. However, it is unclear whether this adequately captures the full range of agricultural chemical, seed, biotechnology, and farm machinery innovations by the private sector, or whether the state to which a patent is assigned reflects where the innovation is adopted by farms.

\section{Science Policy and Incentives for Private Research}

Given the rise of private sector in formal R\&D for agriculture, it is useful to review the theoretical and empirical basis for incentives for agricultural R\&D and how this is affected by public policy. Profit-maximizing firms invest in R\&D up to the point where the marginal cost of research equals its expected marginal revenue, appropriately adjusted for risk and the time lag between when costs are accrued and revenue realized. Dasgupta and Stiglitz (1980) posit three main factors that influence the returns to private research: the size of the market for a new technology, the R\&D costs of developing the new technology (which is a function of the state of applied science, the cost of R\&D inputs, and the time and cost for regulatory approvals), and the degree of appropriability (the share of total economic benefits of the new technology that the innovating firm can capture).

Public policies have an important influence on all of these factors. Public investments in research can expand technological opportunities available for

return on a project under prevailing market conditions, it is not clear to us that the MIRR does a better job of communicating to policy makers the value of investments like research that have long but uncertain benefit horizons. 
private $R \& D$ to commercialize, although public $R \& D$ that competes directly as an alternative supplier of farm technology can crowd out private R\&D. Regulatory protocols affect the cost and time of bringing new agricultural inputs to the market place, and market concentration and IPRs can affect appropriability.

\subsection{Intellectual Property Rights for Biological Innovations}

Over the 20th century, biological inventions intended for agriculture were gradually extended IPR protection, after a long period of ineligibility. Asexual plants (excluding food tubers) were granted protection in 1930 under the Plant Patent Act, and sexually reproducing plants (and tubers) received a weaker form of IPR (plant variety protection certificates [PVPCs]) in 1970, with the Plant Variety Protection Act. A decade later, the Supreme Court ruled multicellular living plants and animals were eligible for full utility patent protection (Diamond v. Chakrabarty [1980]).

At each juncture, three questions can be asked. First, how much did new IPRs increase the appropriability of innovations? Second, did stronger appropriability lead to more R\&D? Third, did more R\&D lead to improved innovation outputs? Efforts to assess the impact of stronger IPRs on innovation outside of agriculture have proved inconclusive (for a summary, see Cohen 2010). As summarized here, it is likewise difficult to draw a direct connection between improved IPRs and research outputs in agriculture.

The 1930 Plant Patent Act created the first IPRs in the United States for plants. Plant patents do appear to be valuable to breeders. Drew et al. (2015) find a plant patent for ornamentals (the vast majority of plant patents) is associated with a $23.5 \%$ price premium on average (the premium varies widely by species) that declines by $0.3 \%$ per year over the life of the patent.

Although this is suggestive that plant patents help firms appropriate the value of their innovations, it is difficult to say whether they have spurred new R\&D in plant breeding. Moser and Rhode (2011) examine the impact of the Plant Patent Act on the American rose, which accounted for nearly half of all plant patents between 1931 and 1970. On the one hand, the number of rose patents grew rapidly after 1930, in tandem with the emergence of a large commercial growing sector. This suggests that the Plant Patent Act provided the IPR infrastructure necessary for a private growing sector to emerge. However, the rate of new rose registrations with the American Rose Society actually fell after plant patents were introduced (Moser and Rhode note a number of confounding factors associated with World War II that may explain this).

The 1970 Plant Variety Protection Act extended IPR protection more broadly, but its saved seed and research exemptions limit the value of PVPCs. Other breeding companies are permitted to use the genetic stock of a high-yielding plant with a PVPC to develop a slightly different but equally high-yielding plant, thus dissipating sales of the original high-yielding variety (Janis and Kesan, 2002). 
Moreover, enforcement of PVPCs is costly because firms must enforce their own rights (Hayes, Lence, and Goggi, 2009). It is perhaps not surprising that PVPCs are not very valuable to firms. Lesser (1994) finds that a PVPC is associated with just a $2.3 \%$ price premium for soybeans, whereas Alston and Venner (2002) find no apparent effect of the Plant Variety Protection Act on wheat seed prices over the period 1954-1994. In Canada, similar IPRs were surrendered or revoked in half of a sample of 105 canola plants (Carew and Devadoss, 2003), and Janis and Kesan (2002) report that the Pioneer seed company-which holds a large number of PVPCs-engaged in no license infringement lawsuits based solely on PVPCs, during 1997-2001. Over the same period, Pioneer initiated 15 patent lawsuits and was sued 11 times for patent infringement.

All that said, it is important not to overstate the case. Clearly PVPCs have some value. After all, they are still sought by many firms every year. Moreover, several studies have shown the enactment of the Plant Variety Protection Act led to an increase in R\&D spending for crops eligible for the new protection. Perrin, Kunnings, and Ihnen (1983) and Butler and Marion (1985) surveyed seed breeding companies on their R\&D activities around the time of the act's passage and found substantial increases in R\&D activity on newly protected plants such as soybeans and, to a lesser extent, cereals (some surveyed firms explicitly stated that they started breeding programs in response to the passage of the Plant Variety Protection Act). Malla and Gray (2001) and Malla, Gray, and Phillips (2004) provide similar evidence that new IPRs stimulated R\&D in a Canadian context.

The evidence that the Plant Variety Protection Act improved research outputs is weaker. Perrin, Kunnings, and Ihnen (1983) and Babcock and Foster (1991) were unable to detect a statistically significant shift in soybean and tobacco yields, respectively, after 1970, when the act passed, despite apparent increases in private soybean $R \& D$ spending and the dominance of the private sector in tobacco breeding. Carew and Devadoss (2003) detected a positive impact of plant breeders' rights on Canadian canola yields in some specifications, but this effect disappeared when time fixed effects were included. Naseem, Oehmke, and Schimmlpfennig (2005) did find a net positive effect of PVPCs on U.S. cotton yields, when they allowed for a trend break in yield growth in 1982. Alston and Venner (2002) found no evidence of higher wheat yields for varieties with PVPCs, but Kolady and Lesser (2009), who were able to control for several omitted factors, found that PVPCs were indicative of higher yields for one of the two wheat varieties they considered. Hayes, Lence, and Goggi (2009), summarizing earlier studies, noted that under controlled conditions the rate of yield gain (in $\mathrm{kg} / \mathrm{ha} /$ year) in European wheat increased faster than in U.S. wheat, which they argued was consistent with more R\&D being induced by factors that tended to make PVPCs more valuable in Europe. On the other hand, Thomson (2015) found the rate of wheat yield improvement worsened after switching to a private system in Australia. 
Although sexual and asexual plants were both eligible for IPRs after 1970, the IPRs available to sexually reproducing plants were significantly weaker than those available to asexual plants. This changed in 1980, when the Supreme Court ruled in Diamond v. Chakrabarty (1980) that plants and animals cannot be excluded from utility patent protection, a decision reaffirmed and clarified in ex parte Hibberd (1985) and ex parte Allen (1987). Utility patents provide 20 years of excludability to the assignee, with no exemptions for researchers or farmers, so long as the patented innovation is novel, useful, and nonobvious. Internationally, in 1995 the World Trade Organization's Agreement on Trade-Related Aspects of Intellectual Property Rights also came into force, requiring plants to be protected by patents or another sui generis system (for example, PVPCs) in all signatory countries.

Utility patents appear to be important in agricultural biotechnology, if not agriculture generally. By examining a range of proxies for patent quality, Lippoldt (2015) shows agricultural patents relating to biocides, foods, and animal husbandry are lower quality, whereas Schneider (2011) shows plant biotechnology patents are high quality (when compared with the typical patent). Schneider (2011) also documents that plant biotechnology patents in the European Union are challenged as not meeting patent eligibility guidelines nearly twice as often as the typical patent. Because it is costly to challenge patents, they are most likely to be challenged when they actually cordon off valuable territory in technological space. The high level of technology fees and royalties in the global seed market (up to 50\% for cotton; Fuglie et al., 2011) also hints at the importance of patents in this sphere, because IPRs are crucial for negotiating royalties and license fees. Finally, Cohen (2010) summarizes the literature on the value of utility patents, which generally finds they are most valuable to medical, health, and chemical industries, sectors that draw on a similar scientific basis and are subject to regulatory oversight in similar ways to agricultural biotechnology.

Although utility patents are likely very valuable in agricultural biotechnology, there is little in the way of attempts to measure how changes in utility patent law affect agricultural firm R\&D decisions or firm R\&D outputs. Perhaps the closest is a study by Lippoldt (2015), which shows that an index of patent strength is positively correlated with more agricultural patents across 41 countries. Again, the evidence is at least consistent with better IPRs leading to more R\&D and improved R\&D outcomes. As noted earlier, the crop improvement and biotechnology sectors have been leading the rapid rise in private R\&D spending. Agricultural biotechnology patents have also grown rapidly since 1980 . For every 1,000 patents granted, the number of agricultural biotechnology patents has grown from 1.5 in 1980 to 3.1 in 1990 to 8.2 in 2000 (USDA-ERS, 2005; U.S. Patent and Trademark Office, 2016).

Lippoldt (2015) also shows that the number of agricultural patents granted in a country is correlated with various measures of agricultural productivity including domestic value added in agricultural exports, cereal crop yields, 
and agricultural equipment imports, although not TFP growth in agriculture (moreover, it should be noted Lippoldt is not measuring biotechnology patents). Finally, using data on experimental field trials, Nolan and Santos (2012) show biotechnology contributed substantially to corn yields over the period 19972009. The National Academies of Sciences, Engineering, and Medicine (2016) concurred that genetically engineered (GE) traits were contributing to actual yield increases but noted there was no evidence that rates of yield gain in farmers' fields had accelerated. This could imply that GE technology was replacing other sources of yield growth in corn.

There are a host of factors that complicate a simple model where stronger IPRs lead to more investment in R\&D and therefore more innovation. However, the evidence does suggest that plant IPR extensions lead to more investment in R\&D. Across the three IPR extensions considered, it appears PVPCs may have some modest impact on the ability of firms to appropriate the value of their new innovations, while plant and utility patents increase appropriability substantially more. Nonetheless, even the weak increase in appropriability associated with PVPCs induced more R\&D spending in eligible crops, although this did not generally translate into significant R\&D outputs. For the stronger IPRs associated with plant and utility patents, new industries such as the commercial rose and agricultural biotechnology sectors emerged in the wake of better IPRs. Although the value of patents in these industries is consistent with them playing an important role, it is not clear how much patents actually contributed to their development, especially in the rose industry. The case is probably strongest for agricultural biotechnology, which seems to rely heavily on the kind of licensing that is facilitated by IPRs.

\subsection{Market Concentration, Competition, and Antitrust Policy}

As agricultural input sectors became important sources of new technologies for farmers, significant structural changes occurred: in particular, the industries became more concentrated, usually through mergers and acquisitions (M\&A). By 2009, more than half of global sales of crop seed, agricultural chemicals, veterinary pharmaceuticals, and farm machinery were accounted for by the four leading firms in each of these sectors, a substantial increase in 15 years (Table 2). The industries also became more closely linked, as several large agricultural chemical companies acquired significant presence in the seed sector, and as equipment providers and chemical/seed firms moved into information technology products.

Some studies have investigated the underlying motivations behind M\&A in agricultural input industries. As biotechnology began to be applied to crop improvement, changes in seed industry structure were motivated by a need to combine complementary technology assets, including core germplasm, genetically modified (GM) traits, and biotechnology research tools (Graff, Rausser, and Small, 2003). Marco and Rausser (2008) found that M\&A 
Table 2. Market Concentration and Research Intensity in Global Agricultural Input Industries

\begin{tabular}{|c|c|c|c|c|}
\hline Year & Herfindahl Index & $\begin{array}{l}\text { Four-Firm } \\
\text { Concentration } \\
\text { Ratio } \\
\quad \text { Share of Gl }\end{array}$ & $\begin{array}{l}\text { Eight-Firm } \\
\text { Concentration } \\
\text { Ratio } \\
\text { Market }(\%)\end{array}$ & $\begin{array}{l}\text { Industry R\&D } \\
\text { Intensity } \\
\text { R\&D/Sales }(\%)\end{array}$ \\
\hline \multicolumn{5}{|c|}{ Crop protection chemicals } \\
\hline 1994 & 398 & 28.5 & 50.1 & 7.0 \\
\hline 2000 & 645 & 41.0 & 62.6 & 6.8 \\
\hline 2009 & 937 & 53.0 & 74.8 & 6.4 \\
\hline \multicolumn{5}{|c|}{ Crop seed } \\
\hline 1994 & 169 & 21.1 & 29.0 & 7.5 \\
\hline 2000 & 359 & 33.0 & 43.7 & 12.7 \\
\hline 2009 & 727 & 46.2 & 54.3 & 11.2 \\
\hline \multicolumn{5}{|c|}{ Animal health } \\
\hline 1994 & 510 & 32.4 & 57.4 & 8.6 \\
\hline 2000 & 657 & 41.8 & 67.4 & 8.5 \\
\hline 2009 & 827 & 50.6 & 72.0 & 8.6 \\
\hline \multicolumn{5}{|c|}{ Farm machinery } \\
\hline 1994 & 264 & 28.1 & 40.9 & 1.9 \\
\hline 2000 & 353 & 32.8 & 44.7 & 2.3 \\
\hline 2009 & 791 & 50.1 & 61.4 & 2.7 \\
\hline
\end{tabular}

Source: Fuglie et al. (2011).

activity in the seed industry occurred partly in response to overlapping patent rights in new plant biotechnologies and high transaction costs in negotiating cross-licensing agreements. In a review of factors affecting M\&A activity in agricultural input industries, Fuglie et al. (2011) found motivations to be specific to each industry. The emergence of biotechnology and the need to acquire complementary technology assets affected the structure of both the crop seed and animal breeding industries. In the animal health industry, increased concentration was largely an outcome of M\&A among (their parent) pharmaceutical firms and was motivated by developments within the much larger market for human pharmaceuticals. Consolidation in the farm machinery industry was one consequence of a farm-sector recession in the 1980s, when farms significantly reduced purchases of new machinery. In the agricultural chemical industry, when new regulations mandated greater health and safety testing of new and existing chemical products, many companies with limited R\&D capacity sold their assets rather than invest in the technological capacity to meet these requirements (Ollinger and Fernandez-Cornejo, 1998; see Section 4.3).

The input sectors cited in Table 2 are broadly defined; concentration can be much greater, often with only 1, 2, or 3 competitors, in narrower but economically relevant markets such as corn seed, pork genetics, fungicides for potatoes, or planters. Growing concentration, particularly in the seed sector, raises concerns about the exercise of market power in the pricing of agricultural 
inputs, the effects of concentration on innovation, and the range of technological options available to farmers and consumers.

Many of these markets combine high and growing concentration with IPR in specific products. IPR provides firms with monopoly power over protected products and therefore with the ability to set price well in excess of marginal costs for commercially successful products. Similarly, firms in highly concentrated markets-with few competitors-may be able to set prices above marginal costs and thereby also be in a position to appropriate more of the returns to innovations. Joseph Schumpeter first proposed that if concentration does provide stronger innovation incentives, the long-term welfare gains from greater innovation could more than offset the short-term welfare losses from higher input prices because of monopoly power.

This "Schumpeterian" view of concentration and innovation receives mixed support in the broader literature on innovation, firm size, and market power (Gilbert, 2006). An influential “neo-Schumpeterian" literature argues, on theoretical and empirical grounds, that the relation between competition and innovation is instead "hump shaped" (Aghion and Griffith, 2005; Aghion et al., 2005). That is, reductions in competition are initially associated with increased innovation through the aforementioned appropriability channel. However, at low levels of competition a further reduction in rivalry leads to reductions in R\&D and innovation: with no close rivals, firms have limited incentives to invest in R\&D and innovation because they will only be cannibalizing their own sales and have little fear of a rival scooping them with new products or processes.

A primary weakness of the neo-Schumpeterian view is that it provides no firm guidance on inflection points beyond which reduced competition weakens innovation. However, it does find support in recent antitrust policy. Since the mid-1990s, antitrust enforcement agencies have been increasingly likely to cite potential reductions in innovation when they challenge mergers (Gilbert, 2006). Indeed, in 2016 the Department of Justice argued that the combination of John Deere's line of high-speed planters with its major rival, a unit of Monsanto, would reduce innovation in the industry when it opposed Deere's proposed acquisition.

To assess the impact of concentration in an R\&D-intensive industry like crop seed, studies have attempted to gauge whether increased concentration resulted in more or less $R \& D$ investment by the industry, or whether firm profits have been excessive relative to their R\&D spending. Schimmelpfennig, Pray, and Brennan (2004) found that as the number of companies conducting field trials with GM crops declined, the total number of GM field trials (relative to seed sales) also declined. They concluded that less competition reduced R\&D investment by the seed industry. However, other factors, such as learning by doing as the industry gained experience with GM crop development, may also have led companies to reduce GM field trials, without necessarily reducing their R\&D spending or rate of crop improvement. Kalaitzandonakes, Magnier, and Miller 
(2010-2011) compared industry profits resulting from price markups for seed to industry R\&D spending on crop breeding and genetic improvement in the United States during 1997-2008. Although their estimates of R\&D spending are only approximate, their results suggest that industry profits did not fully cover R\&D spending until 2007. Moreover, Magnier, Kalaitzandonakes, and Miller (2010) found that product life cycles in the U.S. seed industry appeared to be shortening, implying an accelerated rate of crop improvement. Finally, Fuglie et al. (2011), using new estimates of market concentration and R\&D spending by the seed, agricultural chemical, veterinary pharmaceutical, and farm machinery industries worldwide over 1994-2010, found no major change in the research intensities ( $R \& D$ spending as a percentage of industry sales) of these industries despite significant increases in market concentration (measured by the Herfindahl index and four- and eight-firm concentration ratios) in these industries over this period (Table 2).

Another concern that has been expressed about rising concentration in input industries is that it could limit technological choices by farmers and consumers. With only a few companies accounting for most R\&D spending in these industries worldwide, critical decisions about the kinds of technologies to develop (e.g., GM or non-GM varieties), for what crops, and for what production environments may rest with a relatively small number of corporate boards. Byerlee and Fischer (2002) noted that the great majority of GM applications to agriculture focused on only a few crops (mainly corn, soybean, and cotton) and just two traits (herbicide tolerance and insect resistance conferred by the $b t$ gene). However, it is unlikely that concentration in the seed industry explains these patterns of GM crop development. For example, Naylor et al. (2004) argue that the public sector has also been guilty of neglecting biotechnology development for "orphan crops" (which they define as crops that receive little scientific focus relative to their importance for food security in the world's poorest regions). Rather, lack of consumer acceptance of unprocessed GM foods, absence of regulatory frameworks, poorly defined or enforced IPR, and the small size of potential markets seem to be the major constraints to broader R\&D investment in crop biotechnology (Byerlee and Fischer, 2002; Alston, Bradford, and Kalaitzandonakes, 2006).

One indicator of whether an industry remains open to new technological opportunities and innovations is its ability to attract venture capital for startup companies. Venture capital is especially attracted to technologies that, if successful, could potentially transform an industry (Gompers and Lerner, 1999). Fuglie et al. (2011) traced entrants and exits of 77 small agricultural biotechnology start-up companies between 1979 and 2010. Most of these start-ups exited after just a few years, either through bankruptcy or, if their technologies demonstrated proof of concept, through acquisition by a larger company that then incorporated the technology into its R\&D portfolio. The 
study found that despite frequent exits, the number of active companies grew and then remained roughly constant at between 30 and 40 each year after 1998. Although the number of new entrants appeared to diminish after the world financial crisis of 2007, Fuglie (2016) reported a surge in new venture capital financing for food and agricultural innovations in 2014 and 2015. Although funding of new start-ups in agricultural biotechnology continued to be significant, a large share of the increase in venture capital was for applications of new information and communication technologies to food and agriculture (e.g., e-commerce food marketing and precision farming).

The 2014-2015 downturn in commodity prices and pressure from activist investors appear to have renewed interest in further consolidation among leading agricultural input companies, particularly in the seed-biotechnology-chemical sector. In December 2015, Dow Chemical and Dupont announced a merger, with the intent of spinning off their combined agriculture business into a standalone entity; in February 2016, Syngenta accepted an acquisition offer from ChemChina, and in May 2016, Bayer proposed to buy Monsanto. Together, these actions would shrink the "big six" global agricultural/biotech/seed companies to a big four, and could further increase concentration in a range of already highly concentrated seed and agricultural chemicals markets. This raises the prospect that concentration may reach a point where it negatively affects the amount and diversity of R\&D in these industries. Nonetheless, economics research so far offers little guidance on whether or when an innovation tipping point may be reached.

\subsection{Regulation}

Governments regulate the introduction of new food and agricultural technologies to assure the health and safety of people and the environment, as well as other social goals. Regulations impose costs on new product development and influence incentives for the amount and direction of private R\&D. Regulations may also affect market structure by giving a competitive advantage to firms that have greater financial and technical capacities to meet regulatory requirements.

In the United States, the 1972 and 1978 amendments to the Federal Insecticide, Fungicide and Rodenticide Act (FIFRA) imposed stricter health and safety requirements on agricultural pesticides, requiring manufacturers to collect and submit data evaluating the toxicity effects of new and existing pesticides and to establish dosage and use limits. In an assessment of how FIFRA affected innovation in the pesticide industry, Ollinger and Fernandez-Cornejo (1995) found that although FIFRA encouraged firms to develop less toxic pesticides, it also raised the costs of new pesticide development. This discouraged firms from developing new pesticides for minor crop markets. In a subsequent study, Ollinger and Fernandez-Cornejo (1998) found that the higher "sunk costs" of regulation contributed to consolidation in the pesticide industry, leading to fewer, larger firms, and encouraged foreign firms to expand in the U.S. market. Surveys 
sponsored by the pesticide industry claim that the cost of bringing a new pesticide to market has continued to rise, exceeding $\$ 280$ million by 2010 (Phillips McDougall, 2016). Fuglie et al. (2011) found that new pesticide registrations in the United States fell significantly following the 1970s amendments to FIFRA. R\&D spending by the U.S. pesticide industry has not grown in real terms since in the mid-1980s, although this also reflects slow growth in demand for pesticides due in part to the development of biotechnology substitutes for pest control (Fuglie et al., 2011).

The emergence of agricultural biotechnology in the 1980s led governments to develop new regulatory protocols for this technology. Since 1986, in the United States multiple federal agencies oversee the testing and approval of agricultural biotechnologies (for an overview, see Cowan, 2015). Economic studies on the effects of biotechnology regulations on private $R \& D$ have shown, first, that they impose large fixed costs on GM crop development, and second, that this has likely led private companies to focus agricultural biotechnology R\&D on large markets. Kalaitzandonakes, Alston, and Bradford (2007) estimated the costs of fulfilling regulatory requirements were between $\$ 6.2$ million and $\$ 15.4$ million per GM event. Industry assessments have been even higher. From a survey of the six leading agricultural biotechnology companies, Phillips McDougall (2011) estimated that the total cost of discovery, development, and bringing to market a plant biotechnology trait averaged \$136 million, of which \$17.9 million was to meet regulatory science requirements and another $\$ 17.2$ million was for registration and regulatory affairs costs (the first component includes the cost of the field, greenhouse, and laboratory tests to confirm food, feed, and environmental safety, and the second component includes the cost to prepare, submit, and manage submissions to the regulatory agencies of multiple countries for cultivation and import approvals).

Another cost element is the extent to which meeting regulatory requirements may delay product commercialization. The Phillips McDougall (2011) survey estimated that development activities related to regulation took 7-9 years to complete. However, as these activities are generally conducted concurrently with breeding and wide-area testing, it is not clear whether regulatory protocols, where they have been established, have substantially delayed GM crop commercialization. Nonetheless, regulatory uncertainty-whether or when protocols will be established or significantly changed-has likely been an impediment to the commercialization of agricultural biotechnology and may have negatively affected private $R \& D$ investment decisions.

The high fixed cost of GM crop development and commercialization partly explains why most private $R \& D$ investments in GM crops have focused on crops offering large seed markets like corn, soybean, and cotton. A larger market allows fixed development costs to be spread more widely. In contrast, relatively little private R\&D has been directed toward GM development for fruits and vegetables. With its diversity of species and varieties, seed markets for particular 
GM events would be relatively small. Incentives for private R\&D for GM fruits and vegetables have also been constrained by consumer resistance and, to some extent, greater technical complexity in GM modification for desired traits for these crops (Alston, Bradford, and Kalaitzandonakes, 2006). Although there has been some private biotechnology R\&D directed toward these crops (and GM successes, such as virus-resistant papaya), the amount of R\&D appears to be considerably below that directed to field crops.

Similar to agricultural chemicals and GM crops, new veterinary pharmaceuticals and vaccines require regulatory review. Similar to agricultural chemicals and GM traits, industry surveys point to large and rising costs of meeting regulatory requirements (International Federation for Animal Health, 2011). Uncertainty regarding future regulations, particularly governing antibiotic use in animals, is cited by industry as a disincentive to invest in R\&D to develop new veterinary pharmaceuticals and biologicals. However, there is a general lack of economic research to objectively assess the implications of regulations on R\&D and technological development in animal health.

\subsection{Are Public and Private Agricultural RひD Complements or Substitutes?}

To complete our survey of the potential impacts of increased private investment in agricultural $R \& D$, we review the possible ways public and private investments interact. One view of public-private roles in science and technology is that they are complementary: publicly funded science expands the set of new technological opportunities available for private business to develop and commercialize. In this way, public $R \& D$ raises the marginal returns to private $R \& D$ and therefore stimulates more private R\&D investment. However, when both public and private $R \& D$ are focused on applied applications in an economic sector, their activities may be duplicative. If public R\&D produces technologies that directly compete with technologies from the private sector, the increased competition could reduce what the private firms could charge for their technologies. Facing lower returns to its R\&D investments, private R\&D spending could be "crowded out" by public R\&D.

Empirical studies have sought to test these views of public and private R\&D in agriculture by (1) comparing the nature and kind of R\&D each sector undertakes to see how similar or different they may be and (2) using econometric models to test whether R\&D spending in one sector influences R\&D spending in the other. King, Toole, and Fuglie (2012) split public and private food and agricultural R\&D spending in the United States into eight subsectors (food, crops, livestock, farm machinery, natural resources, etc.) and showed that for most of these subsectors, either public or private R\&D was dominant (Figure 8). Nearly all R\&D on food and farm machinery was private, whereas the public sector was the main provider of R\&D for a number of socially important issues like environment and natural resources, food nutrition and safety, economics and statistics, and community development. The public sector also dominated animal 


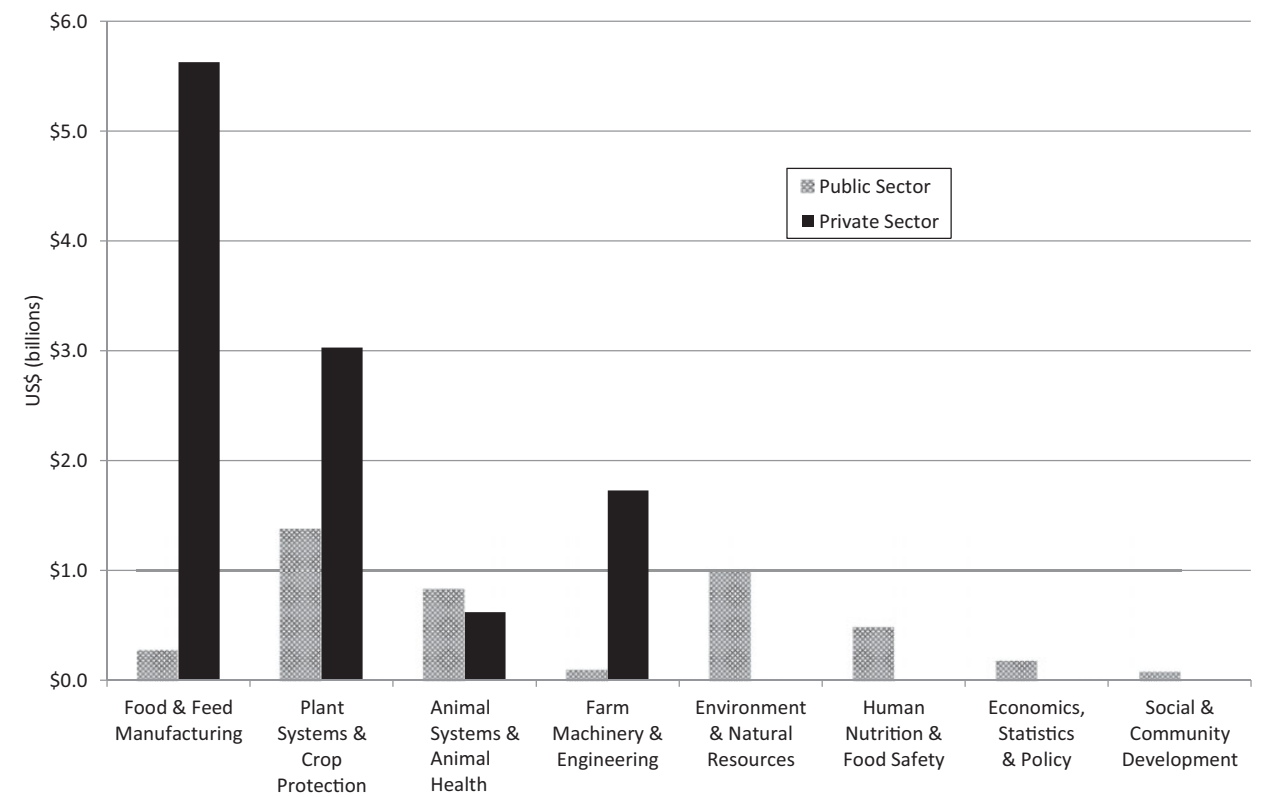

Figure 8. Composition of Public and Private Food and Agricultural R\&D Spending in 2013 (source: Clancy, Fuglie, and Heisey, 2016)

R\&D except for animal health product development. The important exception appeared to be crop research, where each sector spent significant amounts on R\&D.

Focusing on crop breeding, Frey (2000) conducted a near-complete 1994 census of public and private plant breeders to make detailed comparisons of their time allocation across commodities and where their work was situated along the basic-applied R\&D spectrum. He found that even though the private sector employed nearly twice as many plant breeders $(1,499)$ as the public sector (706), $80 \%$ of private-sector breeders were concentrated on applied cultivar development. ${ }^{14}$ More basic, upstream research on germplasm

14 More current plant breeding information is not as complete as that provided by Frey (2000). However, it is likely that the number of public breeders working on applied cultivar development has declined since Frey's study. Traxler et al. (2005) demonstrated a reduction in the number of SAES plant breeders working on cultivar development between 1994 and 2001. Carter et al. (2014) estimated the number of public-sector breeding programs focusing on cultivar development declined by about onethird between 1993 and 2013. Recently, Sylak-Glassman et al. (2016) found that since 2001, state level public institutions decreased the number of plant breeders working on cultivar development for 10 crops or classes of crops, including corn, soybeans, pasture and forage crops, and tomatoes, in most cases even after accounting for nonresponse bias. Only for a few crops, notably several fruit crops and beans, did the number of public-sector plant breeders engaged in cultivar development appear to increase. Second, they reported 71 instances of the cessation of public-sector cultivar development programs between 2005 and 2015. 
enhancement and basic plant breeding tools was emphasized by public-sector plant breeders. Private crop breeding was also more concentrated on a narrow set of commodities: nearly half $(48 \%)$ of private breeding was allocated to just three crops (corn, soybean, and cotton), while the share of public breeding to these crops was just $17 \%$. The differences in the nature and focus of public and private crop improvement research provide further evidence of complementarity.

Econometric analysis to examine behavioral interactions between public and private agricultural R\&D draws its conceptual framework from a broader literature that asks if public $R \& D$ complements or substitutes for private $R \& D$ (David, Hall, and Toole, 2000; Toole, 2007). Complementarity takes place when public R\&D investments stimulate additional private $R \& D$ investments. Substitution takes place when private firms have reduced their own investment relative to a situation without public funding. In regression analyses, finding a positive and significant effect of public R\&D on private R\&D is taken as evidence of a complementary relationship, whereas a negative and significant coefficient indicates substitution.

Most of the econometric studies of public-private interaction in agricultural R\&D focus on the United States and generally find evidence of complementarity. Applying a regression model to Frey's (2000) data on public and private plant breeding investment on 84 commodities, Fuglie and Walker (2001) found that commodities with higher levels of public basic research (basic breeding and germplasm enhancement), after controlling for market size and other factors, were associated with higher private applied R\&D (cultivar development). However, they also found that higher public applied research (cultivar development) was associated with less private applied R\&D, suggesting the possibility of crowding out in applied R\&D. Using time series data on R\&D spending over 1970-2009 in a vector autoregression model, Wang et al. (2013) found that a shock (exogenous spending increase) to public crop research caused private crop research to rise, but no significant interactions were found between public and private livestock research. Wang et al. (2013) also found that a shock to private applied crop research caused public applied crop research to fall. These results suggest the public sector responded to the changing market and institutional environment by reallocating its research portfolio in a way that avoided direct competition with the private sector.

Studies have also found evidence that the New Biology may have provided a significant stimulus to private investment in agricultural R\&D. These studies have found significant complementarities between public life sciences research and agricultural research by the private sector. Using the Standard and Poor's Compustat database for the period 1991-2003, Wang, Xia, and Buccola (2009) estimated an elasticity of private agricultural $R \& D$ with respect to public life sciences research of 0.65 (i.e., a $1 \%$ increase in public life sciences research leads to a $0.65 \%$ increase in private agricultural R\&D). Tokgoz (2006), using different measures for public and private R\&D, got similar results. She found that public 
basic life sciences research had an elasticity of 0.69 on private agricultural R\&D but found no significant relationship between public applied life sciences research and private agricultural R\&D.

Evidence of short-run substitution between public and private sources of funding of bioscience at U.S. universities was found by Buccola, Ervin, and Yang (2009). Based on a national survey of U.S. academic bioscience researchers in 2003-2004, Buccola, Ervin, and Yang found that individual scientists tended to specialize in their sources of research funding and that an increase in private funding led to a decrease in public funding (and vice versa) for that scientist. This could cause crowding out in funding sources in the short run but would not likely affect the system level in the longer run given entry and exit possibilities of new scientists or scientists from related fields.

\section{Conclusions and Areas for Further Research}

Whether U.S. agriculture has entered a period of declining or stagnant productivity growth is not yet clear. It has been difficult to extract a clear signal on this question from the noise in indexes of TFP that arise from the effects of nature and measurement error. The implications of slowing productivity growth in U.S. agriculture would likely mean declining international competitiveness and falling exports, and if such a slowdown occurred in agriculture worldwide, it could have profound consequences for global food and environmental security (Baldos and Hertel, 2014).

Models to explain the growth in agricultural TFP have clearly identified investment in R\&D capital, especially by public institutions, as a prime driver. However, the agricultural innovation system in the United States is undergoing profound change. The rise of private-sector agricultural $R \& D$ and greater potential for knowledge spillovers from New Biology and other countries may mean less dependency on public agricultural R\&D for future growth in U.S. agricultural productivity. On the other hand, none of these sources of innovations are perfect substitutes. A more complete understanding of how knowledge flows among the various components of the national and global agricultural innovation system, and the distinct roles of each component, is needed for informed science policy. This more complex innovation system implies that science policy is about much more than how to allocate public R\&D resources but is increasingly concerned with how to create and enhance incentives to facilitate knowledge spillovers throughout the innovation system.

An important dimension for public policy is how it influences the growth and direction of private food and agriculture $R \& D$. Public R\&D investments can stimulate private $\mathrm{R} \& \mathrm{D}$ by opening up new technological opportunities for private firms to commercialize. Scientific advances in molecular biology and genetic engineering, for example, gave rise to private R\&D in agricultural biotechnology. However, public R\&D can also crowd out private $R \& D$ if it 
competes directly as a supplier of new technologies. Most evidence, however, suggests that public and private agricultural $R \& D$ have been complementary, at least in the United States. Evidence also points to contributions from broader (public) life science research and applied (private) agricultural research.

Other policies that influence private $R \& D$ incentives include provision and enforcement of IPRs, the regulatory regimes governing the introduction of new technologies, and antitrust or competitiveness policies. Affirming the patentability of biological inventions increased the willingness of private firms to investment in crop breeding and biotechnology trait development. The evidence is less clear for plant breeders' rights, however, as the farmer and research exemptions dilute their exclusionary power. Although the establishment of regulatory protocols for new chemical, biological, and pharmaceutical technologies for agriculture have helped to assuage (but not eliminate) consumer concerns about the health and safety of these technologies, obtaining approvals can impose significant costs and delays on technology development. These costs reduce incentives for private $R \& D$ and may discourage investment in technologies that serve relatively small markets but can help direct technology development in socially beneficial directions. Antitrust (competitiveness) policy has thus far not been an impediment to the growing market concentration in agricultural input industries, and M\&A activity may enable firms to acquire complementary technology assets, particularly for crop biotechnology. However, a new round of M\&A among major agricultural chemical and seed firms proposed in 2015-2016 appears likely to involve closer antitrust scrutiny. Because a significant motivation behind these M\&A appears to be cost reduction, if approved they could significantly affect $R \& D$ spending by these industries.

This review suggests a number of areas where additional economics research could be particularly useful for helping inform public and private agricultural science and technology investments and policy:

- The growth rate in TFP has been a workhorse performance standard for agriculture. However, TFP only includes outputs and inputs valued by the market and ignores nonmarket environment services used or produced by agriculture. How would agricultural productivity performance change if TFP was extended to include nonmarket inputs and outputs, into a measure of TRP? What would changes in TRP imply about social returns to public agricultural $\mathrm{R} \& \mathrm{D}$ and other policies that affect agricultural demand for these resources?

- Empirical studies have claimed that public investments in agricultural R\&D have yielded high returns to society. Given the limitations of traditional measures like the IRR and the MIRR, what are appropriate metrics for comparing returns among investments in social capital and communicating these comparisons to policy makers? 
- One way to view the rise of private agricultural $R \& D$ is that it represents, indirectly, a gradual shift in the burden of financing R\&D from general tax revenues to technology fees (input price markups) paid by farmers for agricultural inputs. What has this implied for the incidence of welfare costs and benefits from technical change in agriculture? How has this affected the stability of R\&D funding and the responsive of agricultural R\&D to evolving market demands? How do these outcomes compare with more direct measures to fund public R\&D through producer levies?

- What are the short-term and long-term effects of rising concentration and market power in agricultural input industries? Does it raise prices farmers pay for inputs? How has concentration affected the amount and diversity of private $\mathrm{R} \& \mathrm{D}$ ? Is there a tipping point where concentration reduces incentives to invest in private $R \& D$ ?

- Overlapping patent claims and high transaction costs of cross-licensing technologies have been identified as behind much of the M\&A activity in the crop seed/biotechnology industry. However, in recent years cross-licensing of proprietary technologies over crop germplasm and biotechnology traits has become widespread in this industry. What institutional, legal, or economic factors enabled the use of cross-licensing to grow? How has it affected market competition and pricing behavior in the industry?

- Have instruments of science policy (IPR, regulation, public R\&D, technology transfer and extension services, R\&D subsidies, etc.) influenced the direction of private R\&D in socially desirable ways? For example, have they provided more environmentally friendly technologies or healthy and safer foods? Have they been able to encourage technology development for more diverse markets (horticulture, organic, local foods, nutritious traits, and small farms)?

- Increasingly, voluntary food product standards (e.g., organic, local foods, sustainability, animal welfare, and fair pricing) are influencing the choice of technology in farm and food systems. How are these affecting the amount and direction of public and private R\&D and technical change in agriculture?

- To what extent does U.S. agriculture borrow or benefit from technology developed in other countries? What are the mechanisms through which such international technology transfer takes place?

\section{References}

Aghion, P., N. Bloom, R. Blundell, R. Griffith, and P. Howitt. "Competition and Innovation: An Inverted-U Relationship.” Quarterly Journal of Economics 120,2(2005):701-28.

Aghion, P., and R. Griffith. Competition and Growth: Reconciling Theory and Evidence. Cambridge, MA: MIT Press, 2005.

Alston, J. "The Benefits from Agricultural Research and Development, Innovation, and Productivity Growth.” Organization for Economic Cooperation and Development (OECD) Food, Agriculture and Fisheries Working Papers, No. 31, Paris: OECD, 2010. 
Alston, J., M. Andersen, J. James, and P. Pardey. "The Economic Returns to U.S. Public Agricultural Research.” American Journal of Agricultural Economics 93,5(2011):125777.

- Persistence Pays: U.S. Agricultural Productivity Growth and the Benefits from Public R\&D Spending. New York: Springer, 2010.

Alston, J., M. Andersen, and P. Pardey. "The Rise and Fall of U.S. Farm Productivity Growth, 1910-2007.” Staff paper P15-02, St. Paul: Department of Applied Economics, University of Minnesota, 2015.

Alston, J., J. Beddow, and P. Pardey. “Agricultural Research, Productivity, and Food Prices in the Long Run.” Science 325,5945(2009):1209-10.

Alston, J., K. Bradford, and N. Kalaitzandonakes. "The Economics of Horticultural Biotechnology." Journal of Crop Improvement 18,1-2(2006):413-31.

Alston, J., and P. Pardey. "Agriculture in the Global Economy." Journal of Economic Perspectives 28,1(2014):121-46.

- Making Science Pay: The Economics of Agricultural R\&D Policy. Washington, DC: AEI Press, 1996.

Alston, J., and R. Venner. "The Effects of the US Plant Variety Protection Act on Wheat Genetic Improvement.” Research Policy 31,4(2002):527-42.

Andersen, M.A., J.M. Alston, and P.G. Pardey. "Capital Services in U.S. Agriculture: Concepts, Comparisons, and the Treatment of Interest Rates." American Journal of Agricultural Economics 93,3(2011):718-38.

Andersen, M.A., and W. Song. "The Economic Impact of Public Agricultural Research and Development in the United States." Agricultural Economics 44,3(2013):287-95.

Babcock, B., and W. Foster. "Measuring the Potential Contribution of Plant Breeding to Crop Yields: Flue-Cured Tobacco, 1954-87.” American Journal of Agricultural Economics 73,3(1991):850-59.

Baldos, U., and T. Hertel. "Global Food Security in 2050: The Role of Agricultural Productivity and Climate Change." Australian Journal of Agricultural and Resource Economics 58,4(2014):554-70.

Ball, E., D. Schimmelpfennig, and S.L. Wang. "Is U.S. Agricultural Productivity Growth Slowing?" Applied Economic Perspectives and Policy 35,3(2013):435-50.

Ball, E., S.L. Wang, R. Nehring, and R. Mosheim. "Productivity and Economic Growth in U.S. Agriculture: A New Look?” Applied Economic Perspectives and Policy 38,1(2016):3049.

Bean, C., C. Broda, T. Ito, and R. Kroszner. Low for Long? Cause and Consequences of Persistently Low Interest Rates. Geneva: International Center for Monetary and Banking Studies, Geneva Reports on the World Economy No. 17, 2015.

Beintema, N., G. Stads, K. Fuglie, and P. Heisey. ASTI Global Assessment of Agricultural R\&D Spending. Washington, DC: International Food Policy Research Institute, 2012.

Buccola, S., D. Ervin, and H. Yang. "Research Choice and Finance in University Bioscience." Southern Economics Journal 75,4(2009):1238-55.

Butler, L., and B. Marion. The Impacts of Patent Protection on the U.S. Seed Industry and Public Plant Breeding. Madison: Research Division, College of Agricultural and Life Sciences, University of Wisconsin-Madison, North Central Regional Research Publication 304, 1985.

Byerlee, D., and K. Fischer. "Accessing Modern Science: Policy and Institutional Options for Agricultural Biotechnology in Developing Countries." World Development 30,6(2002):931-48. 
Carew, R., and S. Devadoss. "Quantifying the Contribution of Plant Breeders' Rights and Transgenic Varieties to Canola Yields: Evidence from Manitoba." Canadian Journal of Agricultural Economics 51,3(2003):371-95.

Carter, T.E. Jr., W.F. Tracy, T.R. Sinclair, T.G. Isleib, and R. Joost. "What Is the State of Public Cultivar Development?" Proceedings of the 2014 Summit on Seeds and Breeds for 21st Century Agriculture, Washington, DC, March 5-7, 2014. W.F. Tracy and M. Sligh, eds. Pittsboro, NC: Rural Advancement Foundation International, 2014, pp. 52-73.

Chambers, R.G. "Thinking about Agricultural Productivity Accounting in the Presence of ByProducts.” Paper presented at OECD Expert Workshop: Measuring Environmentally Adjusted Total Factor Productivity for Agriculture, Paris, France, December 14-15, 2015.

Chavas, J., and T. Cox. "A Nonparametric Analysis of the Influence of Research on Agricultural Productivity.” American Journal of Agricultural Economics 74,3(1992):583-91.

Clancy, M., K. Fuglie, and P. Heisey. "U.S. Agricultural R\&D in an Era of Falling Public Funding.” Amber Waves, November 10, 2016. Internet site: https://www.ers.usda.gov/ amber-waves/2016/november/us-agricultural-rd-in-an-era-of-falling-public-funding/ (Accessed June 7, 2017).

Cohen, W. "Fifty Years of Empirical Studies of Innovative Activity and Performance." Handbook of Economics of Innovation. Vol. 1. B. Hall and N. Rosenberg, eds. Amsterdam: Elsevier, 2010, pp. 129-213.

Conner, J.M. "Food Product Proliferation: A Market Structure Analysis.” American Journal of Agricultural Economics 63,4(1981):607-17.

Council of Economic Advisors. Long-Term Interest Rates: A Survey. Washington, DC: Executive Office of the President, 2015.

Cowan, T. Agricultural Biotechnology: Background, Regulation, and Policy Issues. Washington, DC: U.S. Congress, Congressional Research Service, CRS Report 7-5700, 2015.

Dasgupta, P., and J. Stiglitz. "Industrial Structure and the Nature of Innovative Activity." Economic Journal 90,358(1980):266-93.

David, P.A., B. Hall, and A. Toole. "Is Public R\&D a Complement or Substitute for Private R\&D? A Review of the Econometric Evidence.” Research Policy 29,4-5(2000):497-529.

Drew, J., C. Yue, N. Anderson, and P. Pardey. "Premiums and Discounts for Plant Patents and Trademarks Used on Ornamental Plant Cultivars: A Hedonic Price Analysis." HortScience 50,6(2015):879-87.

Evenson, R.E. "Agriculture." Government Support of Technological Progress: A Cross Industry Analysis. R. Nelson, ed. New York: Pergamon Press, 1982, pp. 233-82.

Frey, K. "A National Strategy for Plant Breeding in the United States." Public-Private Collaboration in Agricultural Research. K. Fuglie and D. Schimmelpfennig, eds. Ames: Iowa State University Press, 2000, pp. 77-98.

Fuglie, K. “Accounting for Growth in Global Agriculture." Bio-based and Applied Economics 4,3(2015):201-34.

. "The Growing Role of the Private Sector in Agricultural Research and Development World-Wide." Global Food Security 10(September 2016):29-38.

- "Is a Slowdown in Productivity Growth Contributing to the Rise in Commodity Prices?" Agricultural Economics 39,S1(2008):431-41.

Fuglie, K., and P. Heisey. Economic Returns to Public Agricultural Research. Washington, DC: U.S. Department of Agriculture, Economic Research Service, Economic Brief No. $10,2007$. 
Fuglie, K., P. Heisey, J. King, C. Pray, K. Day-Rubenstein, D. Schimmelpfennig, S.L. Wang, and R. Karmarkar-Deshmukh. Research Investments and Market Structure in the Food Processing, Agriculture Input and Biofuel Industries Worldwide. Washington, DC: U.S. Department of Agriculture, Economic Research Service, Economic Research Report No. 130, 2011.

Fuglie, K., and A. Nin-Pratt. “Agricultural Productivity: A Changing Global Harvest.” IFPRI 2012 Global Food Policy Report. Washington, DC: International Food Policy Research Institute, 2013, pp. 15-28.

Fuglie, K., and A. Toole. "The Evolving Institutional Structure of Public and Private Agricultural Research.” American Journal of Agricultural Economics 96,3(2014):86283.

Fuglie, K., and T. Walker. "Economic Incentives and Resource Allocation in U.S. Public and Private Plant Breeding." Journal of Agricultural and Applied Economics 33,3(2001):459-73.

Fuglie, K., and S. L. Wang. "Productivity Growth in Global Agriculture Shifting to Developing Countries." Choices 27,4(2012):1-7.

Fuglie, K., S.L. Wang, and E. Ball, eds. Productivity Growth in Agriculture: An International Perspective. Wallingford, UK: CAB International, 2012.

Galizzi, G., and L. Venturini, eds. Economics of Innovation: The Case of Food Industry. Heidelberg, Germany: Physica-Verlag, 1996.

Gardner, B. American Agriculture in the Twentieth Century: How It Flourished and What It Cost. Cambridge, MA: Harvard University Press, 2002.

Gardner, B., D. Durost, W. Lin, Y.-C. Lu, G. Nelson, and N. Whittlesey. Measurement of U.S. Agricultural Productivity: A Review of Current Statistics and Proposals for Change. Washington, DC: U.S. Department of Agriculture, Economics, Statistics, and Cooperatives Service, Technical Bulletin No. 1614, 1980.

Gilbert, R. "Competition and Innovation." Journal of Industrial Organization Education 1,1(2006):8.

- "Looking for Mr. Schumpeter: Where Are We in the Competition-Innovation Debate?" Innovation Policy and the Economy. Vol. 6. A.B. Jaffe, J. Lerner, and S. Stern, eds. Cambridge, MA: National Bureau of Economic Research, 2006, pp. 159-215.

Gollop, F.M., and G.P. Swinand. "From Total Factor to Total Resource Productivity: An Application to Agriculture." American Journal of Agricultural Economics 80,3(1998):577-83.

Gompers, P., and L. Lerner. The Venture Capital Cycle. Cambridge, MA: MIT Press, 1999.

Graff, G.D., G.C. Rausser, and A.A. Small. "Agricultural Biotechnology's Complementary Intellectual Assets." Review of Economics and Statistics 85,2(2003): 349-63.

Griliches, Z. "Research Expenditures, Education, and the Aggregate Agricultural Production Function.” American Economic Review 54,6(1964):961-74.

Hayes, D.J., S.H. Lence, and S. Goggi. "Impact of Intellectual Property Rights in the Seed Sector on Crop Yield Growth and Social Welfare: A Case Study Approach." AgBioForum 12,2(2009):155-71.

Huffman, W., and R. Evenson. Science for Agriculture: A Long-Term Perspective. 1st ed. Ames: Iowa State University Press, 1993.

- Science for Agriculture: A Long-Term Perspective. 2nd ed. Ames, IA: Blackwell, 2006.

Hurley, T.M., X. Rao, and P.G. Pardey. "Re-examining the Reported Rates of Return to Food and Agricultural Research and Development." American Journal of Agricultural Economics 96,5(2014):1492-504. 
International Federation for Animal Health (IFAH). IFAH Global Benchmarking Survey 2011. Paris: IFAH, 2011.

International Food Policy Research Institute (IFPRI). Agricultural Science and Technology Indicators (ASTI) [database]. Internet site: https://www.asti.cgiar.org/ (Accessed March 2016).

Janis, M., and J. Kesan. "U.S. Plant Variety Protection: Sound and Fury...?" Houston Law Review 39(2002):727.

Jin, Y., and W.E. Huffman. "Measuring Public Agricultural Research and Extension and Estimating Their Impacts on Agricultural Productivity: New Insights from U.S. Evidence." Agricultural Economics 47,1(2016):15-31.

Jorgenson, D.W., M.S. Ho, and J.D. Samuels. "What Will Revive U.S. Economic Growth? Lessons from a Prototype Industry-Level Production Account for the United States." Journal of Policy Modeling 36,4(2014):674-91.

Kalaitzandonakes, N., J. Alston, and K. Bradford. "Compliance Costs for Regulatory Approval of New Biotech Crops.” Nature Biotechnology 25,5(2007):509-11.

Kalaitzandonakes, N., A. Magnier, and D. Miller. "A Worrisome Crop: Is There Market Power in the U.S. Seed Industry?” Regulation 33,4(2010-2011):20-26.

King, J., A. Toole, and K. Fuglie. The Complementary Roles of the Public and Private Sectors in U.S. Agricultural Research and Development. Washington, DC: U.S. Department of Agriculture, Economic Research Service, Economic Brief No. 19, 2012.

Kolady, D.E., and W. Lesser. "But Are They Meritorious? Genetic Productivity Gains under Plant Intellectual Property Rights.” Journal of Agricultural Economics 60,1(2009):6279.

Lesser, W. "Valuation of Plant Variety Protection Certificates." Review of Agricultural Economics 16,2(1994):231-38.

Lippoldt, D. "Innovation and the Experience with Agricultural Patents since 1990: Food for Thought." Organization for Economic Cooperation and Development (OECD) Food, Agriculture and Fisheries Working Papers, No. 73, Paris: OECD, 2015.

Magnier, A., N. Kalaitzandonakes, and D.J. Miller. "Product Life Cycles and Innovation in the US Seed Corn Industry." International Food and Agribusiness Management Review 13,3(2010):17-36.

Malla, S., and R. Gray. "An Analytical and Empirical Analysis of the Private Biotech R\&D Incentives.” Paper presented at the Annual Meeting of the Agricultural and Applied Economics Association, Chicago, IL, August 5-9, 2001.

Malla, S., R. Gray, and P. Phillips. "Gains to Research in the Presence of Intellectual Property Rights and Research Subsidies." Review of Agricultural Economics 26,1(2004): 63-81.

Marco, A.C., and G.C. Rausser. "The Role of Patent Rights in Mergers: Consolidation in Plant Biotechnology.” American Journal of Agricultural Economics 90,1(2008):133-51.

Moser, P., and P. Rhode. "Did Plant Patents Create the American Rose?" National Bureau of Economic Research (NBER) Working Paper No. 16983, Cambridge, MA: NBER, 2011.

Naseem, A., J.F. Oehmke, and D.E. Schimmelpfennig. "Does Plant Variety Intellectual Property Protection Improve Farm Productivity? Evidence from Cotton Varieties.” AgBioForum 8,2-3(2005):100-107.

National Academies of Sciences, Engineering, and Medicine. Genetically Engineered Crops: Experiences and Prospects. Washington, DC: National Academies Press, 2016.

National Research Council. A New Biology for the 21st Century. Washington, DC: National Academies Press, 2009. 
Naylor, R.L., W.P. Falcon, R.M. Goodman, M.M. Jahn, T. Sengooba, H. Tefera, and R.J. Nelson. "Biotechnology in the Developing World: A Case for Increased Investments in Orphan Crops." Food Policy 29,1(2004):15-44.

Nolan, E., and P. Santos. "The Contribution of Genetic Modification to Changes in Corn Yield in the United States." American Journal of Agricultural Economics 94,5(2012):1171-88.

Oehmke, J.F. "Re-examining the Reported Rates of Return to Food and Agricultural Research and Development: Comment." American Journal of Agricultural Economics 99,3(2017):818-26.

Ollinger, M., and J. Fernandez-Cornejo. Regulation, Innovation, and Market Structure in the U.S. Pesticide Industry. Washington, DC: U.S. Department of Agriculture, Economic Research Service, Agricultural Economics Report No. 719, 1995.

—. "Sunk Costs and Regulation in the U.S. Pesticide Industry." International Journal of Industrial Organization 16,2(1998):139-68.

Pardey, P., Andersen, M., Craig, B., and J. Alston. InSTePP United States Production Accounts (Version 5, 1949-2007). St. Paul: University of Minnesota, 2012. Internet site: http: //www.instepp.umn.edu/united-states\#Version\%205 (Accessed August 2016).

Pardey, P.G., C. Chan-Kang, J.M. Beddow, and S.P. Dehmer. "Long-Run and Global R\&D Funding Trajectories: The U.S. Farm Bill in a Changing Context." American Journal of Agricultural Economics 97,5(2015):1312-23.

Pardey, P.G., C. Chan-Kang, S.P. Dehmer, and J.M. Beddow. "Agricultural R\&D Is on the Move." Nature 537,7620(2016):301-3.

Perrin, R., K. Kunnings, and L. Ihnen. Some Effects of the U.S. Plant Variety Protection Act of 1970. Raleigh: Department of Economics and Business, North Carolina State University, Economics Research Report No. 46, 1983.

Phillips McDougall. The Cost and Time Involved in the Discovery, Development and Authorisation of a New Plant Biotechnology Derived Trait. A Consultancy Study for CropLife International. Midlothian, UK: Phillips McDougall, 2011.

- The Cost of New Agrochemical Product Discovery, Development and Registration in 1995, 2000, 2005-8 and 2010 to 2014. A Consultancy Study for CropLife International, CropLife America, and the European Crop Protection Association. Midlothian, UK: Phillips McDougall, 2016.

Pray, C., and K. Fuglie. "Agricultural Research by the Private Sector." Annual Review of Resource Economics 7(2015):399-424.

President's Council of Advisors on Science and Technology. Report to the President on Agricultural Preparedness and the Agricultural Research Enterprise. Washington, DC: Executive Office of the President, 2012.

Ruttan, V.W. "Productivity Growth in World Agriculture: Sources and Constraints." Journal of Economic Perspectives 16,4(2002):161-84.

Schimmelpfennig, D.E., C.E. Pray, and M.F. Brennan. "The Impact of Seed Industry Concentration on Innovation: A Study of US Biotech Market Leaders." Agricultural Economics 30,2(2004):157-67.

Schneider, C. "The Battle for Patent Rights in Plant Biotechnology: Evidence from Opposition Fillings." Journal of Technology Transfer 36,5(2011):565-79.

Schultz, T.W. The Economic Organization of Agriculture. New York: McGraw-Hill, 1953.

Shumway, C.R., B.M. Fraumeni, L.E. Fulginiti, J.D. Samuels, and S.E. Stefanou. "Measurement of U.S. Agricultural Productivity: A 2014 Review of Current Statistics and Proposals for Change.” Staff Paper Working Paper Series WP 2015-12, Pullman: School of Economic Sciences, Washington State University, 2015. 
- "U.S. Agricultural Productivity: A Review of USDA Economic Research Service Methods." Applied Economic Perspectives and Policy 38,1(2016):1-29.

Sylak-Glassman, E., C. Clavin, E. Klein, R. Whelan, A. Ressler, and M. Hindman. "Examination of Plant Breeding at U.S. Academic Institutions and Private Companies in 2015." Institute for Defense Analyses (IDA) Paper P-5331, Washington, DC: IDA, 2016.

Thomson, R. "The Yield of Plant Variety Protection." American Journal of Agricultural Economics 97,3(2015):762-85.

Tokgoz, S. "Private Agricultural R\&D in the United States." Journal of Agricultural and Resource Economics 31,2(2006):212-38.

Toole, A.A. "Does Public Scientific Research Complement Private Investment in Research and Development in the Pharmaceutical Industry?" Journal of Law and Economics 50,1(2007):81-104.

Traxler, G., A.K.A. Acquaye, K. Frey, and A.M. Thro. Public Sector Plant Breeding Resources in the US: Study Results for the Year 2001. Washington, DC: U.S. Department of Agriculture, National Institute for Food and Agriculture, 2005.

U.S. Department of Agriculture, Economic Research Service (USDA-ERS). "Agricultural Biotechnology Intellectual Property.” Washington, DC: USDA-ERS, 2005. Internet site: https://wayback.archive-it.org/5923/20120620044601/ http://www.ers.usda.gov/data/ AgBiotechIP/ (Accessed June 26, 2017).

—. "Agricultural Productivity in the U.S." Washington, DC: USDA-ERS, December 14, 2015. Internet site: https://www.ers.usda.gov/data-products/agricultural-productivityin-the-us/ (Accessed June 2016).

- Economic Indicators of the Farm Sector: Production and Efficiency Statistics, 1981. Washington, DC: USDA-ERS, ECIFS 1-3, 1983.

U.S. Patent and Trademark Office. U.S. Patent Statistics Chart: Calendar Years 1963-2015. Arlington, VA: U.S. Patent and Trademark Office, 2016.

Wang, C., Y. Xia, and S. Buccola. "Public Investment and Industry Incentives in Life-Science Research." American Journal of Agricultural Economics 91,2(2009):374-88.

Wang, S.L., V.E. Ball, L.E. Fulginiti, and A. Plastina. "Accounting for the Impact of Local and Spill-in Public Research, Extension and Roads on US Regional Agricultural Productivity, 1980-2004." Productivity Growth in Agriculture: An International Perspective. K.O. Fuglie, S.L. Wang, and V.E. Ball, eds. Wallingford, UK: CAB International, 2012, pp. 13-32.

Wang, S.L., P.W. Heisey, W.E. Huffman, and K.O. Fuglie. "Public R\&D, Private R\&D, and U.S. Agricultural Productivity Growth: Dynamic and Long-Run Relationships.” American Journal of Agricultural Economics 95,5(2013):1287-93.

Wang, S.L., P. Heisey, D. Schimmelpfennig, and E. Ball. Agricultural Productivity Growth in the United States: Measurement, Trends, and Drivers. Washington, DC: U.S. Department of Agriculture, Economic Research Service, Economic Research Report No. 189, 2015.

Wang, S.L., D. Schimmelpfennig, and K.O. Fuglie. "Is Agricultural Productivity Growth Slowing in Western Europe?" Productivity Growth in Agriculture: An International Perspective. K.O. Fuglie, S.L. Wang, and V.E. Ball, eds. Wallingford, UK: CAB International, 2012, pp. 109-26. 